\title{
Emerging therapies for relapsed/refractory multiple myeloma: CAR-T and beyond
}

\author{
Christopher T. Su ${ }^{1,2}$ and J. Christine Ye ${ }^{1,2^{*}}$ (1)
}

\begin{abstract}
The pace of innovation of multiple myeloma therapy in recent years is remarkable with the advent of monoclonal antibodies and the approval of novel agents with new mechanisms of action. Emerging therapies are on the horizon for clinical approval with significant implications in extending patient survival and advancing closer to the goal of a cure, especially in areas of immunotherapy such as chimeric antigen receptor $T$ cells, bispecific $T$ cell engager antibodies, antibody drug conjugates, newer generations of monoclonal antibodies, and small molecule inhibitor and modulators. This review provides an update of current myeloma therapeutics in active preclinical and early clinical development and discusses the mechanism of action of several classes of novel therapeutics.
\end{abstract}

Keywords: Multiple myeloma, Review, First in human trials, Chimeric antigen receptor, CAR-T, Bispecific antibody, T cell engager, Antibody-drug conjugate, Monoclonal antibody, Small molecule inhibitor, Targeted therapy

\section{Introduction}

Although multiple myeloma remains an incurable disease, the 5-year relative survival rate has nearly doubled in the last 20 years, from $32.1 \%$ in 1996 to $54.9 \%$ in 2016 based on National Cancer Institute statistics. Numerous treatment options have entered the myeloma therapeutic landscape in the last 5-10 years, significantly extending progression-free survival (PFS) and overall survival (OS). In addition to IMIDs (immunomodulatory agents) and PIs (proteasome inhibitors), daratumumab, an antiCD38 antibody initially approved for relapsed/refractory patients, is now moving into the frontline setting for newly diagnosed multiple myeloma, therefore adding a third gold standard in the newly diagnosed multiple myeloma therapeutic paradigm $[1,2]$.

Relapsed/refractory multiple myeloma (RRMM) is an extremely active area of research, largely due to the nature of myeloma disease heterogeneity and clonal evolution throughout the disease progression [3, 4]. Drug

*Correspondence: jchrisye@med.umich.edu

${ }^{1}$ Department of Internal Medicine, University of Michigan, Ann Arbor, MI 48109, USA

Full list of author information is available at the end of the article approvals in the last couple of years include selinexor (XOP1 nuclear export inhibitor) and isatuximab (another anti-CD38 monoclonal antibody), which were approved by the Food and Drug Administration (FDA) in July 2019 and March 2020, respectively. Most recently, attesting to the vibrancy of ongoing myeloma research, the firstin-class B-cell maturation antigen (BCMA)-targeted antibody-drug conjugate (belantamab mafodotin) was approved in August 2020 [5], and BCMA-targeted CAR-T cell therapy (idecabtagene vicleucel) in March 2021 [6]. Currently, the landscape of emerging multiple myeloma clinical trials is diverse and encouraging, including chimeric antigen receptor (CAR)-T cells, bispecific T-cell engager antibodies (BiTEs), antibodydrug conjugates (ADCs), newer generations of monoclonal antibodies (MoAbs) and small molecule inhibitors/ modulators (Fig. 1).

This review, as part of "First-in-human clinical trials for cancer therapy" thematic series, aims to discuss novel agents and emerging multiple myeloma therapies, with a special focus on data from early phase clinical trials presented at major 2019-2020 oncology meetings (Table 1) and actively recruiting registered Phase 1 clinical trials

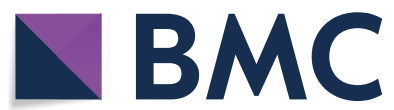

(c) The Author(s) 2021. Open Access This article is licensed under a Creative Commons Attribution 4.0 International License, which permits use, sharing, adaptation, distribution and reproduction in any medium or format, as long as you give appropriate credit to the original author(s) and the source, provide a link to the Creative Commons licence, and indicate if changes were made. The images or other third party material in this article are included in the article's Creative Commons licence, unless indicated otherwise in a credit line to the material. If material is not included in the article's Creative Commons licence and your intended use is not permitted by statutory regulation or exceeds the permitted use, you will need to obtain permission directly from the copyright holder. To view a copy of this licence, visit http://creativecommons.org/licenses/by/4.0/. The Creative Commons Public Domain Dedication waiver (http://creativeco mmons.org/publicdomain/zero/1.0/) applies to the data made available in this article, unless otherwise stated in a credit line to the data. 


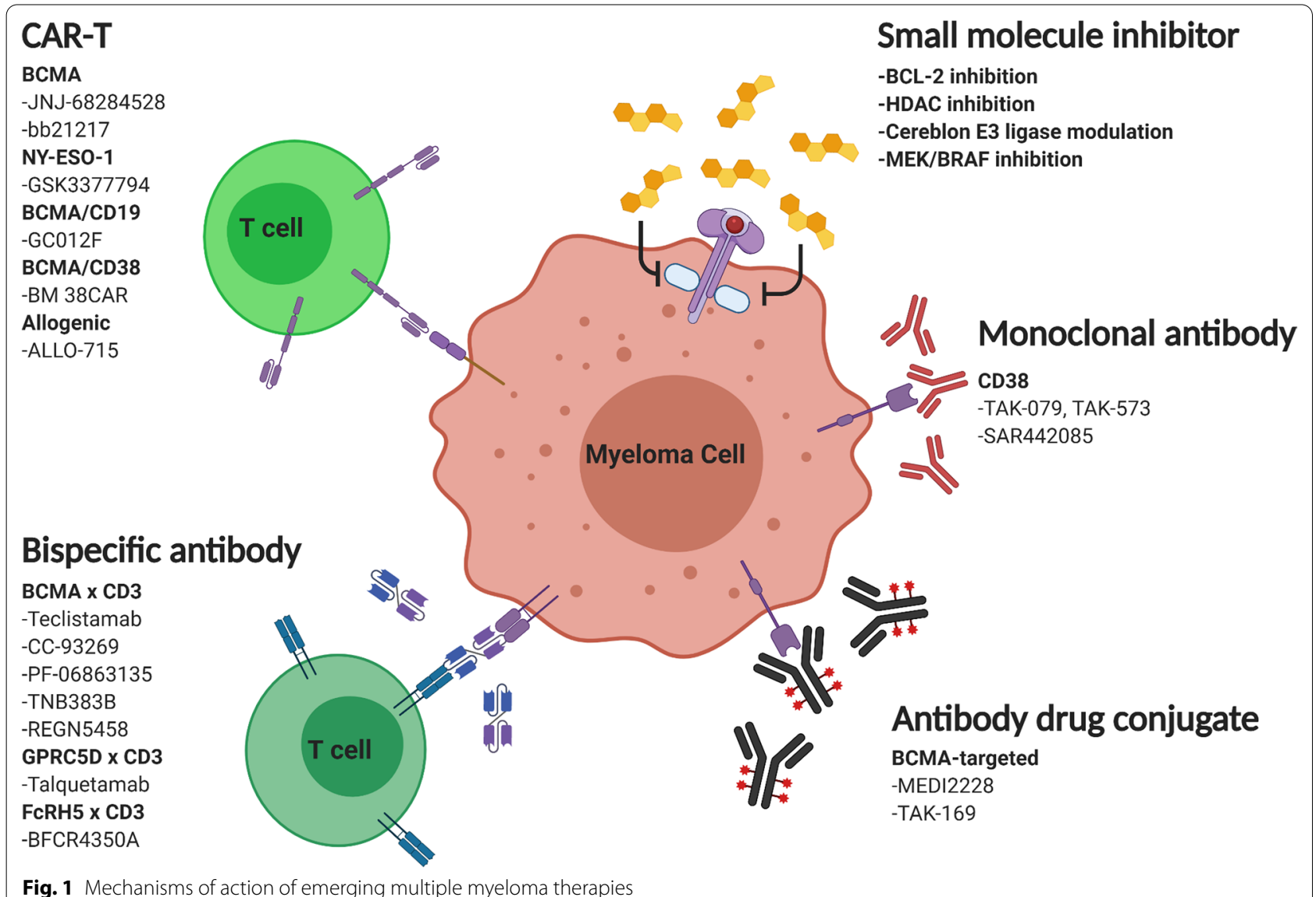

(Fig. 2). The number of substantially increased CAR-T trials since 2018 is especially noteworthy.

\section{Chimeric antigen receptor (CAR)-T cell}

CAR-T therapy revolutionized immunotherapy in myeloma treatment since autologous stem cell transplant (ASCT) [36]. CAR-T therapy can be broadly grouped into three groups: single-target, multi-target, and universal CAR-T (Table 2). The ideal therapeutic CAR-T targets a cell surface antigen that is preferentially, and ideally exclusively, expressed on myeloma cells [37]. Resistance mechanisms such as "on target off tumor" recognition (expression of targeted antigens on normal cells) and "antigen escape" (loss of targeted antigens on tumor cells) pose ongoing therapeutic challenges in CAR-T therapy [38]. As a result, dual-target CAR-T strategies to increase precision of targeting have been proposed. Single-target CAR-T cells express one extracellular single-chain variable fragment recognizing tumor antigens, while dualtarget CAR-T cells utilize co-stimulatory receptor design (separating the T-cell activation domain and the costimulatory domain into two separate CARs) or tandem CARs (two tandem-linked antigen recognition moieties coupled with one activation domain) [39]. Cytokine release syndrome (CRS) and neurotoxicity are significant adverse effects and important considerations for cellular-directed therapy (CAR-T and BiTE). These toxicities along with associated overall response rates for the treatments discussed are summarized in Table 3.

\section{Single-target CAR-T}

Although there are numerous CAR-T candidates in clinical trials, only one CAR-T product is approved for clinical use in multiple myeloma. The most common cellular target in multiple myeloma CAR-T therapies currently is BCMA, a transmembrane glycoprotein in the tumor necrosis factor superfamily which is critical for B-cell differentiation to plasma cells and long-term plasma cell survival [40-42]. Furthermore, BCMA is preferentially expressed on plasma cells and not normal human tissue, including primary human CD34+ hematopoietic cells, making it an attractive target for CAR-T therapy [43]. The CAR-T candidate which has currently advanced the furthest in clinical development is idecabtagene vicleucel, a recent FDA-approved BCMA-directed CAR-T, that reported a $73 \%$ overall response rate (ORR) and 
Table 1 Active clinical trials of novel therapeutic agents for RRMM presented at major oncology meetings, 2019-2020

\begin{tabular}{|c|c|c|c|c|c|}
\hline Antigen & Product name* $(\mathrm{NCT})$ & Study sponsor & Estimated enrollment & Country & $\begin{array}{l}\text { Clinical Update } \\
\text { reference }\end{array}$ \\
\hline \multicolumn{6}{|l|}{ CAR-T cells } \\
\hline BCMA & $\begin{array}{l}\text { JNJ-68284528 } \\
\text { (NCT03548207) }\end{array}$ & Janssen & 118 & United States, Japan & 2020 ASH [7] \\
\hline BCMA & $\begin{array}{l}\text { bb21217 } \\
\text { (NCT03274219) }\end{array}$ & Bluebird & 74 & United States & 2020 ASH [8] \\
\hline NY-ESO-1 & $\begin{array}{l}\text { GSK33777794 } \\
\text { (NCT03168438) }\end{array}$ & GlaxoSmithKline & 20 & United States & 2019 ASH [9] \\
\hline BCMA /CD19 & GC012F (NCT04236011) & $\begin{array}{l}\text { Shanghai Changzheng } \\
\text { Hospital }\end{array}$ & 15 & China & 2020 ASH [10] \\
\hline $\mathrm{BCMA} / \mathrm{CD} 38$ & $\begin{array}{l}\text { BM 38CAR } \\
\quad \text { (ChiCTR1800018143) }\end{array}$ & $\begin{array}{l}\text { Wuhan Tongji Medi- } \\
\text { cal College Union } \\
\text { Hospital }\end{array}$ & 20 & China & 2019 ASH [11] \\
\hline $\mathrm{BCMA}$ & $\begin{array}{l}\text { ALLO-715 } \\
\text { (NCT04093596) }\end{array}$ & Allogene & 90 & United States & 2020 ASH [12] \\
\hline \multicolumn{6}{|l|}{ Bispecific antibody (BiTE) } \\
\hline $\mathrm{BCMA} \times \mathrm{CD} 3$ & $\begin{array}{l}\text { Teclistamab } \\
\text { JNJ-64007957 } \\
\text { (NCT03145181) }\end{array}$ & Janssen & 160 & $\begin{array}{l}\text { United States, the } \\
\text { Netherlands, Spain, } \\
\text { Sweden }\end{array}$ & 2020 ASH [13] \\
\hline $\mathrm{BCMA} \times \mathrm{CD} 3$ & $\begin{array}{l}\text { CC-93269 } \\
\text { (NCT03486067) }\end{array}$ & Celgene & 115 & United States, Spain & 2019 ASH [14] \\
\hline $\mathrm{BCMA} \times \mathrm{CD} 3$ & $\begin{array}{l}\text { PF-06863135 } \\
\quad(\text { NCT03269136) }\end{array}$ & Pfizer & 80 & United States, Canada & 2020 ASH [15] \\
\hline $\mathrm{BCMA} \times \mathrm{CD} 3$ & $\begin{array}{l}\text { TNB-383B } \\
\text { (NCT03933735) }\end{array}$ & Tenebio AbbVie & 72 & United States & 2020 ASH [16] \\
\hline $\mathrm{BCMA} \times \mathrm{CD} 3$ & $\begin{array}{l}\text { REGN5458 } \\
\text { (NCT03761108) }\end{array}$ & Regeneron & 74 & United States, Belgium & 2020 ASH [17] \\
\hline GPRC5D $\times$ CD3 & $\begin{array}{l}\text { Talquetamab } \\
\text { JNJ-64407564 } \\
\text { (NCT03399799) }\end{array}$ & Janssen & 245 & $\begin{array}{l}\text { United States, Nether- } \\
\text { lands, Spain }\end{array}$ & 2020 ASH [18] \\
\hline $\mathrm{FcRH} 5 \times \mathrm{CD} 3$ & $\begin{array}{l}\text { BFCR4350A } \\
\text { (NCT03275103) }\end{array}$ & Genentech & 300 & $\begin{array}{l}\text { United States, Australia, } \\
\text { Canada, Spain }\end{array}$ & 2020 ASH [19] \\
\hline \multicolumn{6}{|l|}{$\begin{array}{l}\text { Antibody-drug conju- } \\
\text { gate (ADC) }\end{array}$} \\
\hline $\begin{array}{l}\text { BCMA, pyrrolobenzodi- } \\
\text { azepine }\end{array}$ & $\begin{array}{l}\text { MEDI2228 } \\
\text { (NCT03489525) }\end{array}$ & Medlmmune & 142 & $\begin{array}{l}\text { United States, Australia, } \\
\text { Greece }\end{array}$ & 2020 ASH [20] \\
\hline $\begin{array}{l}\text { BCMA, Shiga-like toxin- } \\
\text { A subunit (engineered } \\
\text { toxin bodies) }\end{array}$ & TAK-169 (NCT04017130) & Millennium Takeda & 102 & United States & 2019 ASH [21] \\
\hline \multicolumn{6}{|l|}{$\begin{array}{l}\text { Monoclonal antibody } \\
(\mathrm{MoAb})\end{array}$} \\
\hline CD38 & TAK-079 (NCT03439280) & Millennium Takeda & 100 & United States & 2020 ASCO [22] \\
\hline CD38 with interferon & TAK-573 (NCT03215030) & Millennium Takeda & 151 & United States & 2020 ASH [23] \\
\hline CD38 & $\begin{array}{l}\text { SAR442085 } \\
\text { (NCT04000282) }\end{array}$ & Sanofi & 78 & $\begin{array}{l}\text { United States, France, } \\
\text { Spain }\end{array}$ & 2020 AACR[24] \\
\hline \multicolumn{6}{|l|}{$\begin{array}{l}\text { Small molecule inhibitors } \\
\text { and modulators }\end{array}$} \\
\hline BCL-2 inhibitor & $\begin{array}{l}\text { Venetoclax } \\
\text { (NCT03314181, } \\
\text { NCT01794520) }\end{array}$ & AbbVie & 104,117 & $\begin{array}{l}\text { United States, Australia, } \\
\text { Belgium, Canada, } \\
\text { Denmark, France, } \\
\text { Germany, Norway }\end{array}$ & $\begin{array}{l}2019 \text { ASH [25], } 2019 \\
\text { ASH [26] }\end{array}$ \\
\hline BCL-2 inhibitor & AT-101 (NCT02697344) & Mayo Clinic & 10 & United States & 2019 ASH [27] \\
\hline HDAC inhibitor & $\begin{array}{l}\text { Alteminostat } \\
\text { (NCT03150316) }\end{array}$ & $\begin{array}{l}\text { Chong Kun Dang Phara- } \\
\text { maceutical }\end{array}$ & 18 & South Korea & 2019 ASH [28] \\
\hline HDAC inhibitor & $\begin{array}{l}\text { Chidamide } \\
\text { (NCT04025450) }\end{array}$ & $\begin{array}{l}\text { The First Affiliated } \\
\text { Hospital of Soochow } \\
\text { University }\end{array}$ & 50 (high-risk NDMM) & China & 2019 ASH [29] \\
\hline
\end{tabular}


Table 1 (continued)

\begin{tabular}{|c|c|c|c|c|c|}
\hline Antigen & Product name* (NCT) & Study sponsor & Estimated enrollment & Country & $\begin{array}{l}\text { Clinical Update } \\
\text { reference }\end{array}$ \\
\hline $\begin{array}{l}\text { Cereblon E3 ligase } \\
\text { modulator }\end{array}$ & $\begin{array}{l}\text { Iberdomide (CC-220) } \\
\text { (NCT02773030) }\end{array}$ & Celgene & 449 & $\begin{array}{l}\text { United States, France, } \\
\text { Germany, Italy, } \\
\text { Japan, the Nether- } \\
\text { lands, Spain, United } \\
\text { Kingdom }\end{array}$ & 2020 ASH [30] \\
\hline $\begin{array}{l}\text { Cereblon E3 ligase } \\
\text { modulator }\end{array}$ & $\begin{array}{l}\text { CC-92480 } \\
\text { (NCT03374085) }\end{array}$ & Celgene & 80 & $\begin{array}{l}\text { United States, Canada, } \\
\text { Denmark, Finland, } \\
\text { Spain, United King- } \\
\text { dom }\end{array}$ & 2020 ASH [31] \\
\hline MEK inhibitor & $\begin{array}{l}\text { Cobimetinib } \\
\text { (NCT03312530) }\end{array}$ & Hoffmann-La Roche & 72 & $\begin{array}{l}\text { Czechia, Denmark, } \\
\text { France, Germany, } \\
\text { Netherlands, Norway, } \\
\text { Poland, Spain, } \\
\text { Sweden }\end{array}$ & 2020 ASH [32] \\
\hline $\begin{array}{l}\text { MEK and BRAF inhibi- } \\
\text { tors }\end{array}$ & $\begin{array}{l}\text { Encorafenib and } \\
\text { binimetinib } \\
\text { (NCT02834364) }\end{array}$ & University of Heidelberg & 12 & Germany & 2020 ASH [33] \\
\hline \multicolumn{6}{|l|}{ Other therapies } \\
\hline $\begin{array}{l}\text { Peptidase enhanced } \\
\text { cytotoxic }\end{array}$ & $\begin{array}{l}\text { Melflufen } \\
\quad(\text { NCT03481556) }\end{array}$ & Oncopeptides & 80 & $\begin{array}{l}\text { United States, Czechia, } \\
\text { Spain }\end{array}$ & 2020 ASH [34] \\
\hline $\begin{array}{l}\text { Peptidase enhanced } \\
\text { cytotoxic }\end{array}$ & $\begin{array}{l}\text { Melflufen } \\
\text { (NCT02963493) }\end{array}$ & Oncopeptides & 157 & $\begin{array}{l}\text { United States, France, } \\
\text { Italy, Spain }\end{array}$ & 2020 ASCO [35] \\
\hline
\end{tabular}

ASCO American Society of Clinical Oncology, ASH American Society of Hematology, AACR American Association for Cancer Research

*In cases where no unique product name was given, only the NCT number is listed to the bottom of the table (see Table 2 for example)

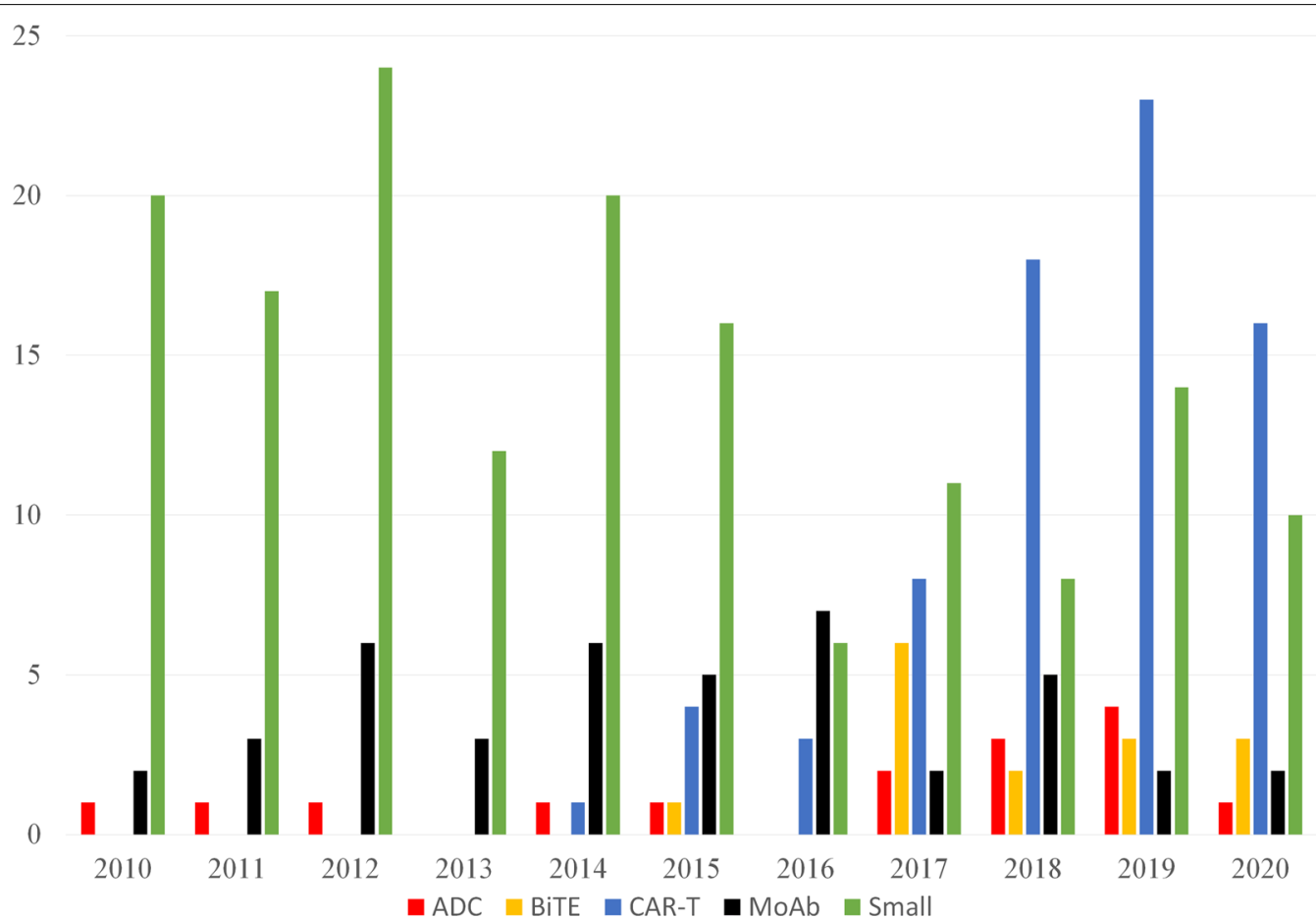

Fig. 2 Phase 1 trials by year and type of studies, 2010-2020. ADC antibody-drug conjugate, BiTE bispecific antibody, CAR-T chimeric antigen receptor T cell, MoAb monoclonal antibody, Small small molecule inhibitor/modulator. Therapies not categorized as one of the above were excluded $(59 / 363,16 \%)$ 
Table 2 Phase 1 and early phase 1 CAR-T trials for RRMM, as of December 31, 2020, with study start date after January 1, 2019

\begin{tabular}{|c|c|c|c|c|}
\hline Antigen & Product name* (NCT) & Study sponsor & $\begin{array}{l}\text { Estimated } \\
\text { enrollment }\end{array}$ & Country \\
\hline \multicolumn{5}{|l|}{ Single-target CAR-T cells } \\
\hline BCMA & IM21 (NCT04537442) & $\begin{array}{l}\text { Beijing Immunochina Medical Science } \\
\text { and Technology }\end{array}$ & 10 & China \\
\hline BCMA & CT053 (NCT03975907) & Carsgen & 62 & China \\
\hline BCMA & NCT04271644, NCT04272151 & Chongqing Precision Biotech & $\begin{array}{l}80 \\
40\end{array}$ & China \\
\hline BCMA & C-CAR088 (NCT03815383) & $\begin{array}{l}\text { First Affiliated Hospital with Nanjing } \\
\text { Medical University }\end{array}$ & 12 & China \\
\hline BCMA & NCT04626752 & Hebei Senlang Biotechnology & 50 & China \\
\hline BCMA & C-CAR088 (NCT03751293) & Hebei Yanda Ludaopei Hospital & 10 & China \\
\hline BCMA & NCT04601935 & Nanjing Legend Biotech & 34 & China \\
\hline BCMA & C-CAR088 (NCT04295018) & $\begin{array}{l}\text { Peking Union Medical College } \\
\text { Hospital }\end{array}$ & 10 & China \\
\hline BCMA & NCT04186052 & PersonGen Bio (Suzhou) & 10 & China \\
\hline BCMA & C-CAR088 (NCT04322292) & $\begin{array}{l}\text { Tianjing Institute of Hematology and } \\
\text { Blood Diseases }\end{array}$ & 10 & China \\
\hline BCMA & NCT04637269 & Xinqiao Hospital of Chongqing & 16 & China \\
\hline BCMA & CARTBCMA ARI0002h (NCT04309981) & $\begin{array}{l}\text { Institut d'Investigacions Biomèdiques } \\
\text { August Pi i Sunyer }\end{array}$ & 36 & Spain \\
\hline BCMA & NCT04155749 & Arcelix & 12 & United States \\
\hline BCMA & CT053 (NCT03915184) & Carsgen & 70 & United States, Canada \\
\hline BCMA & Descartes-11 (NCT03994705) & Cartesian & 18 & United States \\
\hline BCMA & CYAD-211 (NCT04613557) & Celyad Oncology & 12 & United States, Belgium \\
\hline BCMA & CC-98633 (NCT04394650) & Juno/Celgene & 80 & United States \\
\hline BCMA & PHE885 (NCT04318327) & Novartis & 16 & United States \\
\hline CD4 & NCT04162340 & iCell Gene Therapeutics & 12 & China \\
\hline CD22 & NCT03999697 & PersonGen BioTherapeutics (Suzhou) & 10 & China \\
\hline CD44 & MLM-CAR44.1 (NCT04097301) & MolMed S.p.A & 58 & Italy \\
\hline CD138 & NCT03672318 & University of North Carolina & 33 & United States \\
\hline GPRC5D & MCARH109 (NCT04555551) & $\begin{array}{l}\text { Memorial Sloan Kettering Medical } \\
\text { Center }\end{array}$ & 36 & United States \\
\hline $\mathrm{HA}-1$ & MDG1021 (NCT04464889) & Medigene & 29 & The Netherlands \\
\hline SLAMF7 & NCT04499339 & Wuerzburg University Hospital & 38 & Germany \\
\hline SLAMF7 & NCT03958656 & National Cancer Institute & 36 & United States \\
\hline TnMUC1 & NCT04025216 & Tmunity & 112 & United States \\
\hline \multicolumn{5}{|l|}{ Dual-target CAR-T cells } \\
\hline BCMA CD19 & NCT04194931 & $\begin{array}{l}\text { The First Affiliated Hospital of Nan- } \\
\text { chang University }\end{array}$ & 20 & China \\
\hline BCMA CD19 & NCT04162353 & iCell Gene Therapeutics & 12 & China \\
\hline BCMA CD19 & GC012F (NCT04236011) & Shanghai Changzheng Hospital & 15 & China \\
\hline BCMA CD19 & NCT04280328 & Xian Xijing Hospital & 18 & China \\
\hline BCMA CD19 & NCT04603872 & Zhejiang University & 120 & China \\
\hline \multicolumn{5}{|l|}{ Universal CAR-T cells } \\
\hline BCMA & ALLO-715 (NCT04093596) & Allogene & 90 & United States \\
\hline BCMA & CTX120 (NCT04244656) & CRISPR Therapeutics & 80 & United States, Australia, Spain \\
\hline BCMA & PBCAR269A (NCT04171843) & Precision BioSciences & 48 & United States \\
\hline \multicolumn{5}{|l|}{ Other } \\
\hline Anti-BCMA CAR-NK cells & NCT03940833 & Asclepius Technology (Suzhou) & 20 & China \\
\hline PD-L1 plus other antigen & NCT04191941 & Timmune Biotech & 9 & China \\
\hline $\begin{array}{l}\text { CD34 + enriched hematopoietic } \\
\text { progenitor cells expressing } \\
\text { interferon-a2 }\end{array}$ & Temferon (NCT03875495) & Genenta & 9 & Italy \\
\hline $\begin{array}{l}\text { CD8 + T-cells expressing WT1, CD138, } \\
\text { NY-ESO-1, and CS1 }\end{array}$ & NEXI-002 (NCT04505813) & NexImmune & 22 & United States \\
\hline
\end{tabular}

* In cases where no unique product name was given, only the NCT number is listed 
Table 3 Overall response rates, cytokine release syndrome, and neurotoxicity associated with selected cellular-directed therapy

\begin{tabular}{|c|c|c|c|c|c|c|}
\hline Antigen & Product name (NCT) & $\begin{array}{l}\text { Study } \\
\text { enrollment } \\
\text { (n) }\end{array}$ & $\begin{array}{l}\text { Median time } \\
\text { to follow-up } \\
\text { (months) }\end{array}$ & $\begin{array}{l}\text { Overall } \\
\text { response } \\
\text { rate (\%) }\end{array}$ & $\begin{array}{l}\text { Cytokine } \\
\text { release } \\
\text { syndrome (\%) }\end{array}$ & Neurotoxicity (\%) \\
\hline \multicolumn{7}{|l|}{ CAR-T cells } \\
\hline BCMA & JNJ-68284528 (NCT03548207) & 97 & 8.8 & 95 & 95 & 21 \\
\hline BCMA & bb21217 (NCT03274219) & 46 & 8.5 & 55 & 67 & 22 \\
\hline BCMA /CD19 & GC012F (NCT04236011) & 16 & 7.3 & 94 & 88 & 0 \\
\hline BCMA/CD38 & BM 38CAR (ChiCTR1800018143) & 16 & 9.0 & 87.5 & 62.5 & 0 \\
\hline BCMA & ALLO-715 (NCT04093596) & 19 & 2.0 & 60 & 24 & 0 \\
\hline \multicolumn{7}{|c|}{ Bispecific antibody (BiTE) } \\
\hline $\mathrm{BCMA} \times \mathrm{CD} 3$ & $\begin{array}{l}\text { Teclistamab JNJ-64007957 } \\
\text { (NCT03145181) }\end{array}$ & 128 & $\mathrm{n} / \mathrm{a}$ & 64 & 53 & 5 \\
\hline $\mathrm{BCMA} \times \mathrm{CD} 3$ & CC-93269 (NCT03486067) & 19 & 3.7 & 83.3 & 89.5 & $\mathrm{n} / \mathrm{a}$ \\
\hline $\mathrm{BCMA} \times \mathrm{CD} 3$ & PF-06863135 (NCT03269136) & 18 & $\mathrm{n} / \mathrm{a}$ & 33 & 61 & $\mathrm{n} / \mathrm{a}$ \\
\hline $\mathrm{BCMA} \times \mathrm{CD} 3$ & TNB-383B (NCT03933735) & 38 & $\mathrm{n} / \mathrm{a}$ & 37 & 21 & 13 (headache) \\
\hline $\mathrm{BCMA} \times \mathrm{CD} 3$ & REGN5458 (NCT03761108) & 45 & 2.4 & 36 & 38 & $\geq 1$ \\
\hline GPRC5D × CD3 & $\begin{array}{l}\text { Talquetamab JNJ-64407564 } \\
\text { (NCT03399799) }\end{array}$ & 137 & $\mathrm{n} / \mathrm{a}$ & 78 & 47 & 5 \\
\hline $\mathrm{F} C \mathrm{RH} 5 \times \mathrm{CD} 3$ & BFCR4350A (NCT03275103) & 51 & 6.2 & 52 & 75 & $\mathrm{n} / \mathrm{a}$ \\
\hline
\end{tabular}

minimal residual disease (MRD) negativity rate of $26 \%$ in relapsed refractory myeloma patients [6].

The LEGEND-2 trial (LCAR-B38M, NCT03090659, Phase 1, China) utilized a CAR-T design that incorporates two BCMA-targeting single-domain antibodies and one 4-1BB co-stimulatory domain It has enrolled 57 RRMM patients treated with at least 3 prior lines of therapy at four different sites with different conditioning regimens and number of CAR-T cells administered [44]. ORR was $88 \%$, with CR achieved by $74 \%$ of evaluable patients (of which 93\% achieved MRD-negativity). Median OS is not yet reached (at follow-up of 19 months), with OS at 18-months being 68\%. Median PFS was 20 months for all patients, and 28 months for MRD-negative patients. Most common AEs were pyrexia (91\%), CRS (90\%, of which $82 \%$ were grade $1-2)$, leukopenia (30\%), and thrombocytopenia (23\%).

The CARTITUDE-1 trial (JNJ-4528, NCT03548207, Phase 1b, United States and Japan) has enrolled 97 RRMM patients treated with median 6 prior lines of therapy [7]. This study utilized the same CAR-T construct as in LEGEND-2 trial. Cyclophosphamide and fludarabine $(\mathrm{Cy} / \mathrm{Flu})$ was used as the conditioning regimen. ORR was $95 \%$ at median follow-up of 8.8 months, with $56 \%$ stringent complete responses (sCR) in evaluable patients. Median time to first response was 1.0 months, and median duration of response has not been reached. The 6-month PFS and overall survival (OS) rates were $87 \%$ and $94 \%$, respectively. Most common AEs were CRS (95\%, of which $96 \%$ were grade $1-2$ ), neutropenia (91\%), and anemia (81\%). The rate of neurotoxicity was $21 \%$, of which $90 \%$ were grade $1-2$.

The CRB-402 trial (bb21217, NCT03274219, Phase 1, United States) has enrolled 46 RRMM patients treated with median 6 prior lines of therapy [8]. The study utilized a CAR-T construct based on idecabtagene vicleucel, consisting of one anti-BCMA single-chain variable fragment with one intracellular 4-1BB co-stimulatory domain [45]. Cy/Flu was used as the conditioning regimen. Clinical response was seen in $55 \%$ of evaluable patients with median follow-up time of 8.5 months. Median time to CR was 2.5 months and duration of response 11.9 months. AEs reported were CRS (67\%, of which $94 \%$ were grade $1-2$ ) and neurotoxicity (22\%, of which $70 \%$ were grade 1-2). The CRB-401 trial (bb2121, NCT02658929, Phase 1, United States), which uses the same CAR-T construct as bb21217 but lacks the PI3K inhibitor bb007 added to bb21217 during ex vivo culture, similarly demonstrated efficacy and safety with median follow-up of 14.7 months and ORR of $76 \%$ in evaluable patients [46].

Other antigens most recently being explored for single-target CAR-T include CD4, CD22, CD44, CD138, HA-1, SLAMF7/CS1, TnMUC1 (Table 2), among others including CD19, CD38, NY-ESO-1, and numerous others described in literature [47]. The challenge to implement these differing antigen approaches is optimizing ontumor targeting while minimizing toxic effects to normal tissue due to co-expression of myeloma markers. The NY-ESO-1 TCR T trial (GSK3377794, NCT03168438, Phase 1, United States) employs CAR-T targeted against NY-ESO-1, a cancer antigen expressed in diverse tumor 
types, including multiple myeloma $[9,48,49]$. Although only three patients were dosed with the trial medication at time of report, the authors report a $57 \%$ rate of positivity in bone marrow samples for NY-ESO-1 in eligible RRMM patients, suggesting NY-ESO-1 targeting may be a viable novel avenue of approach.

\section{Dual-target CAR-T}

Several dual-target CAR-T trials have recently begun recruitment. All focus on BCMA and CD19 co-expressing CAR-Ts, which has demonstrated significant in vitro cytolytic activity on dual-expressor cells leading to complete tumor remission greater than that of BCMA or CD19 CAR-T alone [50].

The GC012F trial (GC012F, NCT04236011, Phase 1, China) enrolled 16 RRMM patients treated with median 5 prior lines of therapy [10]. The study used a dual-target CAR constructed by linking BCMA and CD19 singlechain variable fragments and $\mathrm{Cy} / \mathrm{Flu}$ was used as the conditioning regimen. ORR was reported as $94 \%$ in evaluable patients, with 56\% reaching MRD-negative sCR at median follow-up time of 7.3 months. CRS occurred in $88 \%$ of patients, of which $88 \%$ were grade $1-2$. No neurotoxicity was observed.

The BM38 CAR trial (BM38 CAR, ChiCTR1800018143, Phase 1, China) enrolled 16 RRMM patients treated with at least 2 prior lines of therapy [11]. The study employed a dual-target CAR incorporating anti-CD38 and antiBCMA antigen-recognition single-chain variable fragments linked in tandem to increase on-target sensitivity. $\mathrm{Cy} / \mathrm{Flu}$ was used as the conditioning regimen. ORR was reported as $87.5 \%$ in evaluable patients, with $50 \%$ reaching sCR. Median PFS still has not been reached, but PFS at 9 months was $75 \%$. The authors report CRS occurring in $62.5 \%$ of patients $(60 \%$ had grade $1-2$, while others had higher grades requiring tocilizumab). No dose limiting toxicities or neurotoxicity at levels higher than grade 3 were reported by the study authors at median follow-up of 36 weeks.

\section{Universal CAR-T/NK}

All CAR-T therapies discussed thus far are autologous in origin, which pose advantages such as long-term persistence of engineered $\mathrm{T}$ cells due to the lack of an allogeneic reaction. However, autologous CAR-T therapy must be opportunely coordinated from harvesting to manufacturing and to final infusion. Some patients may not be able to afford the wait time of an additional 1-2 months due to rapid disease progression. Furthermore, previous lines of therapy that may negatively impact autologous $\mathrm{T}$ cells and $\mathrm{T}$ cell dysfunction are considerations following immunosuppression in the myeloma microenvironment
[36, 51]. Thus, universal CAR-T/NK (UCAR-T/NK) therapy has been proposed as a treatment strategy to address these challenges, with advantages including batch-production and "off the shelf" availability and healthy T cells, but disadvantages including increased risk of graft-versus-host disease (GvHD) [52].

The feasibility of UCAR-T was described in an ex vivo platform which used bulk bone marrow biopsies from newly-diagnosed multiple myeloma (NDMM) and RRMM patients with high risk cytogenetics [53]. Following co-culture, young healthy donor anti-BCMA CAR-T cells against primary $\mathrm{MM}$ cells were able to achieve a specific anti-BCMA CAR-T cell killing rate of $13-73 \%$ while keeping target effects directed away from nontumor cells. However, associated in vivo toxicity remains to be seen.

The ALLO-715 trial (ALLO-715, NCT04093596, Phase 1, United States) reported the first UCAR-T results, enrolling 19 RRMM patients treated with median 5 lines of prior therapy [12]. The study employed anti-BCMA UCAR-T cells with optimization to reduce the risk of GvHD and promote selective prolonged host lymphodepletion. Different conditioning regimens were used in treatment arms. ORR was reported as $60 \%$ in the arm with the highest efficacy, with 1 reaching sCR and all responders reached at least very good partial response (VGPR) and MRD-negativity. The most common AEs greater than grade 3 were anemia (41\%), neutropenia (41\%), and lymphopenia (29\%). One grade $5 \mathrm{AE}$ was reported as a sequela of multifocal pneumonia related to the conditioning regimen. No neurotoxicity or GvHD has yet been seen, with CRS reported in $24 \%$ of patients ( $75 \%$ grade $1,25 \%$ grade 2 ).

Among ongoing UCAR-T trials, the CRISPR-Cas9 platform is being explored for the new generation of CAR-T cells, as the gene editing system is able to construct UCAR-T cells with defective $\mathrm{T}$ cell receptors and class I major histocompatibility complexes, avoiding GvHD and rapid rejection of the host immune system due to these modifications [54].

Furthermore, universal natural killer (NK) cell therapy is also being developed, although therapeutic challenges include specificity, persistence after infusion, and in vivo maximal activity of donor NK products. Phase 1 data of GDA-201 on 15 RRMM patients concurrently receiving elotuzumab showed no dose limiting toxicities and transient adverse effects without neurotoxicity, CRS, or GvHD. Response rate data has not been reported for myeloma patients, although the universal NK cell product demonstrated significant activity against multiplerefractory non-Hodgkin's lymphoma with ORR of $73 \%$ [55]. 
Table 4 Phase 1 and early phase 1 bispecific antibodies (BiTE), antibody-drug conjugates (ADC), and monoclonal antibodies (MoAb) for RRMM, as of December 31, 2020, with study start date after January 1, 2019

\begin{tabular}{|c|c|c|c|c|}
\hline Target antigens & Product name (NCT) & Study sponsor & $\begin{array}{l}\text { Estimated } \\
\text { enrollment }\end{array}$ & Country \\
\hline \multicolumn{5}{|l|}{ Bispecific antibodies (BiTE) } \\
\hline $\mathrm{BCMA} \times \mathrm{CD} 3$ & REGN5459 (NCT04083534) & Regeneron & 56 & United States \\
\hline $\mathrm{BCMA} \times \mathrm{CD} 3$ & TNB-383B (NCT03933735) & Teneobio & 72 & United States \\
\hline $\mathrm{BCMA} \times \mathrm{CD} 3 \times$ albumin ("tri-specific") & HPN217 (NCT04184050) & Harpoon & 70 & United States \\
\hline $\mathrm{BCMA} \times \mathrm{CD} 16 \mathrm{a}$ & RO7297089 (NCT04434469) & Genentech & 80 & Australia, Denmark, Norway \\
\hline $\mathrm{CD} 28 / 38 \times \mathrm{CD} 3$ & SAR442257 (NCT04401020) & Sanofi & 57 & United States \\
\hline GPRC5D $\times$ CD3 and BCMA $\times$ CD3 & Talquetamab and teclistamab (NCT04108195) & Janssen & 100 & $\begin{array}{l}\text { United States, Canada, Ger- } \\
\text { many, the Netherlands, } \\
\text { Spain }\end{array}$ \\
\hline \multicolumn{5}{|l|}{ Antibody-drug conjugates (ADC) } \\
\hline BCMA, monomethyl auristatin- $\mathrm{F}[59]$ & $\begin{array}{l}\text { GSK2857916 (belantamab mafodotin) } \\
\text { (NCT03828292) }\end{array}$ & GlaxoSmithKline & 14 & Japan \\
\hline BCMA, maytansinoid & CC-99712 (NCT04036461) & Celgene & 120 & United States, Canada \\
\hline $\begin{array}{l}\text { BCMA, Shiga-like toxin-A subunit } \\
\text { (engineered toxin bodies) [21] }\end{array}$ & TAK-169 (NCT04017130) & Millennium Takeda & 102 & United States \\
\hline CD46, monomethyl auristatin- $\mathrm{F}[60]$ & FOR46 (NCT03650491) & Fortis & 50 & United States \\
\hline \multicolumn{5}{|l|}{ Monoclonal antibodies (MoAb) } \\
\hline CD38 & SAR442085 (NCT04000282) & Sanofi & 78 & United States, France, Spain \\
\hline CD47 & AO-176 (NCT04445701) & Arch Oncology & 102 & United States \\
\hline $\mathrm{IL}-18$ & AEVI-007 (NCT04671251) & Aevi/Cerecor & 30 & United States \\
\hline
\end{tabular}

\section{Bispecific T-cell engager antibodies (BiTEs)}

Bispecific T-cell engager antibodies (BiTEs), the new kids on the block, comprise another important class of immunotherapies being explored in RRMM. Blinatumomab, an anti-CD19 BiTE for relapsed/refractory B-cell precursor acute lymphoblastic leukemia, was the first to be approved for clinical use in 2014 [56]. These constructs bind concomitantly to $\mathrm{T}$ cells and malignant cells, directing the cytotoxic effect of $\mathrm{T}$ cells selectively against tumor cells. Thus, BiTEs mimic CAR-T cells in mechanism and activity, although they do not require an extensive manufacturing process of viral transduction or donor $\mathrm{T}$ cell harvest. BiTEs join two single-chain variable fragments in tandem via a linker/connector [57]. An alternative DuoBody system is being developed, which utilizes a controlled antigen-binding fragment (Fab) arm exchange of IgG antibodies to create a new bispecific IgG [58]. Although several BiTE constructs are under investigation, none have yet been approved for clinical use for multiple myeloma. Numerous proposed trials from the last 2 years are currently in progress (Table 4).

Teclistamab is a DuoBody bispecific BCMA and CD3 antibody which can be administered both intravenously and subcutaneously. The teclistamab trial (JNJ64007957, NCT03145181, Phase 1, multiple countries) has enrolled 128 RRMM patients treated with median 6 prior lines of therapy in a dose-finding trial [13]. A response rate of $64 \%$ was achieved by all evaluable patients. Median time to first response was 1 month, and median duration of response was not reached, with responding patients remaining on therapy from 2 to 21 months. Most common AEs were anemia (55\%), neutropenia (55\%), and CRS (53\%, all grade 1-2). Grade 3-4 AEs were reported by $39 \%$ of patients, with the most common being neutropenia (23\%) and anemia (9\%). Neurotoxicity was reported by $5 \%$ of patients $(2 \%$ grade 3 or higher).

CC93269 is an asymmetric two arm IgG1-based human BiTE antibody that binds bivalently to BCMA and monovalently to CD3e [61]. The CC-93269-MM-001 trial ( NCT03486067, Phase 1, multiple countries) has enrolled 19 RRMM patients treated with median 6 prior lines of therapy [14].ORR was $83.3 \%$ ( $\geq 6 \mathrm{mg}$ CC-93269 in Cycle 1) in evaluable patients, with $33.3 \%$ achieving sCR and $75 \%$ achieving MRD-negativity at a follow-up interval ranging from 2.1 to 4.7 months. Grade 3-4 AEs were reported in $78.9 \%$ of patients, including neutropenia, anemia, infection, and thrombocytopenia, although no patients required dose modifications due to toxicity. CRS was reported in $89.5 \%$ of patients (of which $94 \%$ had grade 1-2). One death was reported due to CRS, with infection as a possible contributing factor.

The REGN5458 trial (NCT03761108, Phase 1, United States) has enrolled 45 RRMM patients treated with 
median 5 prior lines of therapy in a safety trial with REGN5458, a BiTE antibody also targeting BCMA and CD3 [17]. ORR was 36\% across all dose levels, with $31 \%$ achieving at least CR. Most common AEs include CRS (38\%, all grades $1-2)$, fatigue (18\%), and nausea (18\%), with dose-limiting toxicities including acute kidney injury and elevated liver transaminases. Serious treatment-associated AEs occurred in $22 \%$ of patients; the most common was CRS (11\%).

The TNB383B trial (NCT03933735, Phase 1, United States) has enrolled 38 patients treated with median 7 prior lines of therapy [16]. TNB-383 is a BiTE targeting BCMA and CD3, with proprietary technology optimizing high affinity for BCMA with low-activating CD3 to minimize toxicity due to cytokine secretion from strong activation of CD3. ORR was $37 \%$ in evaluable patients, with a median duration of response of 9 weeks. The most common AEs were CRS (21\%, all grade 1-2) and headache (13\%); the most common grade 3-4 AEs were anemia $(16 \%)$ and thrombocytopenia (13\%).

The PF-06863135 trial (NCT03269136, Phase 1, United States and Canada) has enrolled 18 RRMM patients treated with median 7 prior lines of therapy in a doseescalation safety trial [15]. PF-3135 is another BiTE antibody consisting of BCMA and CD3 targeting arms. ORR was $33 \%$ for evaluable patients ( $75 \%$ at the top two dosing tiers). Most common AEs were CRS (61\%, all had grade $1-2)$, anemia (50\%), and thrombocytopenia (39\%). Grade 3-4 AEs were observed in $67 \%$ of patients; grade 4 AEs included lymphopenia (22\%), thrombocytopenia (17\%), and neutropenia (11\%). Grade 5 AEs occurred in $17 \%$ of patients, but were not thought to be treatment-related.

Bispecific antibodies against other antigens on malignant cells aside from BCMA have also been created. The talquetamab trial (JNJ-64407564, NCT03399799, Phase 1 , multiple countries) has enrolled 137 patients treated with median 6 prior lines of therapy in a dose escalation study with talquetamab, a BiTE antibody targeting GPRC5D and CD3 which can be administered intravenously or subcutaneously [18]. GPRC5D is an orphan receptor with high selective expression in primary myeloma cells [62]. ORR ranged from $78 \%$ (intravenous) to $67 \%$ (subcutaneous) in evaluable patients, with a median onset of response of 1 month. The most frequent AEs included anemia (50\%), CRS (47\%, mostly grade $1-2$, with $<8 \%$ grade 3 ), and neutropenia $(45 \%)$. Neurotoxicity was reported in $5 \%$ of patients (57\% grade $1-2$ ).

The GO39775 trial (BFCR4350A, NCT03275103, Phase 1 , multiple countries) has enrolled 51 patients treated with median 6 prior lines of therapy in a safety trial evaluating BFCR4350A, a BiTE antibody targeting FcRH5 and CD3 [19]. FcRH5 is a membrane protein expressed on B and plasma cells, with almost $100 \%$ expression on observed myeloma cells [63]. ORR was 52\% in evaluable patients, with $40 \%$ of these patients demonstrating durable response 6 months following therapy. The most common AEs were CRS (75\%, of which $97 \%$ were grade $1-2)$, neutropenia (12\%), and thrombocytopenia (10\%).

\section{Antibody-drug conjugates (ADCs)}

Antibody-drug conjugates consist of recombinant monoclonal antibodies covalently bound to cytotoxic chemicals (known as warheads or payload) via synthetic linkers $[64,65]$. Since gemtuzumab ozogamicin for relapsed acute myelogenous leukemia became the first ADC to gain approval by the United States Food and Drug Administration (FDA) in 2010, there has been a total of eight additional approvals. Currently, three generations of ADCs were developed, with enhancing stability and potency while minimizing toxicity in each subsequent generation [64]. Belantamab mafodotin (GlaxoSmithKline) was the first agent approved for RRMM in August 2020 [5].

The MEDI-2228 trial (NCT03489525, Phase 1, multiple countries) has enrolled 82 RRMM patients treated with at least 3 prior lines of therapy in a dose-escalating study testing MEDI-2228, an ADC linking an anti-BCMA antibody which is conjugated to a DNA cross-linking pyrrolobenzodiazepine dimer [20]. Efficacy was seen at all dose levels, with ORR being $61 \%$ at the maximally tolerated dose. Most common AEs occurring at the maximal dose included photophobia (54\%), thrombocytopenia (32\%), and rash (29\%), with no reports of keratopathy or visual acuity loss.

The TAK-169 trial (TAK-169, NCT04017130, Phase 1, United States) plans to enroll 114 RRMM patients in a two-part clinical trial to assess the safety and preliminary clinical activity of TAK169, a fusion protein comprised of an anti-CD38 antibody single chain variable fragment fused to a modified Shiga-like toxin-A subunit [21]. The proposed agent specifically binds to CD38+ cells, undergoes forced internalization of the target cell and retrograde transport to the cytosol, and finally irreversibly inactivates target cell ribosomes causing apoptosis. This mechanism is considered novel from standard ADCs and may be considered as a distinct class of therapeutics (engineered toxin bodies) with continued clinical success. In vitro, in vivo, and ex vivo assays were performed demonstrating significant direct tumor cell kill activity independent of the patient's innate immune status. Current enrollment is ongoing (Table 4), and additional targets, including SLAMF7 with the same therapeutic construct, are being investigated $[66,67]$.

Other targeted antigens include CD123 (tagraxofusp, NCT02661022, phase 1, United States), an antigen 
expressed by plasmacytoid dendritic cells which is also found in the multiple myeloma bone marrow microenvironment [68]. Tagraxofusp is a CD123-directed cytotoxin fused to a truncated diphtheria toxin approved for blastic plasmacytoid dendritic-cell neoplasm [69]. Nine RRMM patients were treated with median 3 lines of prior therapy received tagraxofusp with pomalidomide and dexamethasone, with $56 \%$ reporting partial response in tumor reduction and $>50 \%$ decrease in peripheral blood plasmacytoid dendritic cell levels. The most common AEs were hypoalbuminemia (67\%), chills (56\%), and fatigue (56\%); the most common grade 3-4 AEs were thrombocytopenia (44\%) and neutropenia (33\%), with no grade 5 events reported.

Finally, there are also efforts to create amanitin-based ADCs which are expected to have additional action against non-proliferating myeloma cells in contrast to ADCs utilizing microtubule- or DNA-targeting toxins which are more effective in actively dividing cells. HDP101 is a new ADC targeting BCMA linked to amanitin especially aimed at targeting myeloma cells with TP53 deletions in chromosome 17p [70]. Amanitin is active against RNA polymerase II, of which a major subunit is frequently co-deleted with TP53 in cells with chromosome 17p deletions [71]. Preclinical studies demonstrated efficacy and tolerance [72]; clinical trials are forthcoming.

\section{Monoclonal antibodies (MoAbs)}

Since 2015, monoclonal antibodies have become a stalwart of RRMM therapy, with recent approval of daratumumab as the frontline treatment in NDMM [73]. Currently, there are three FDA-approved monoclonal antibodies: daratumumab (anti-CD38), elotuzumab (antiSLAMF7), and isatuximab (anti-CD38).

The TAK-079 trial (NCT03439280, Phase 1, United States) has enrolled 34 RRMM patients treated with median 4 prior lines of therapy in the TAK-079 trial [22]. TAK-079 is a subcutaneously administered anti-CD38 antibody that induces apoptosis via antibody-dependent cellular cytotoxicity and complement-dependent cytotoxicity [74]. At the recommended phase 2 dose, the authors report a preliminary efficacy of ORR 33\% in evaluable subjects who received at least 6 cycles of therapy. The clinical benefit rate at the recommended phase 2 dose (minimal response or better) was 67\%, with PFS not estimable given the current median follow-up of 7.5 months. The most common AEs were fatigue (21\%), anemia (18\%), neutropenia (18\%), and leukopenia (15\%), with only neutropenia being the only grade $3 \mathrm{AE}$. The only drug-related significant $\mathrm{AE}$ was grade 3 diverticulitis, with no grade $4 \mathrm{AEs}$, AEs leading to study discontinuation, or deaths secondary to AEs.
A related anti-CD38 therapeutic trial, TAK-573 (NCT03215030, Phase 1, United States) is currently in progress and has enrolled 59 patients with median 7 lines of prior therapy in a phase 1 dose-finding trial [23]. TAK573 , designed for directed interferon delivery contains an anti-CD38 monoclonal antibody fused to two attenuated interferon molecules. Response has been seen at nearly all dosing levels, with most common AEs being thrombocytopenia ( $83 \%, 47 \%$ grade 3 and above) and neutropenia ( $54 \%, 49 \%$ grade 3 and above).

SAR442085 is another anti-CD38 antibody currently beginning phase I trials (NCT04000282, Phase 1, multiple countries) [24]. The authors report that SAR442085 has a higher affinity for activating receptors on effector cells compared to daratumumab, resulting in an increased ability to engage CD16 with a higher level of NK cell activation.

Other target antigens currently being explored include CD47 (AO-176, NCT03834948, Phase 1, United States), an innate immune checkpoint found to be overexpressed on cancer cells [75-77]. AO-176 was found to not only promote phagocytosis of hematologic tumor cell lines but also directly target and kill tumor cells. Animal in vivo studies show complete tumor regression combined with bortezomib, including improved overall survival. Enrollment in phase 1 trial is ongoing for RRMM (NCT04445701).

\section{Small molecule inhibitors and modulators}

Small molecule inhibitors and modulators comprise the final major class of multiple myeloma therapy. Currently approved therapies include proteasome inhibitors (bortezomib, carfilzomib, ixazomib), immunomodulators (lenalidomide, pomalidomide, thalidomide), histone deacetylase inhibitors (panobinostat), and the novel nuclear export inhibitor, selinexor, which was approved July 2019 [78]. Figure 3 is a schematic of the major pathways of approved small molecule therapeutics described in this review, with current FDA-approved therapies for multiple myeloma highlighted in red text and investigational therapeutics in blue text. Phase 1 targeted therapy trials in this category initiated since 2019 are listed in Table 5.

\section{BCL-2/MCL-1 inhibitors}

Venetoclax is an oral inhibitor of the BCL-2 protein which regulates the intrinsic mitochondrial apoptotic pathway as an anti-apoptotic. Venetoclax binds to BCL-2 and terminates the suppression of proapopotic proteins BAX and BAK, promoting cell death of the target cell (Fig. 3). Venetoclax is approved for chronic lymphocytic leukemia and acute myeloid leukemia and was further explored in RRMM, initially as single agent and later in combination with Velcade $[79,80]$. Due to BCL-2 and 


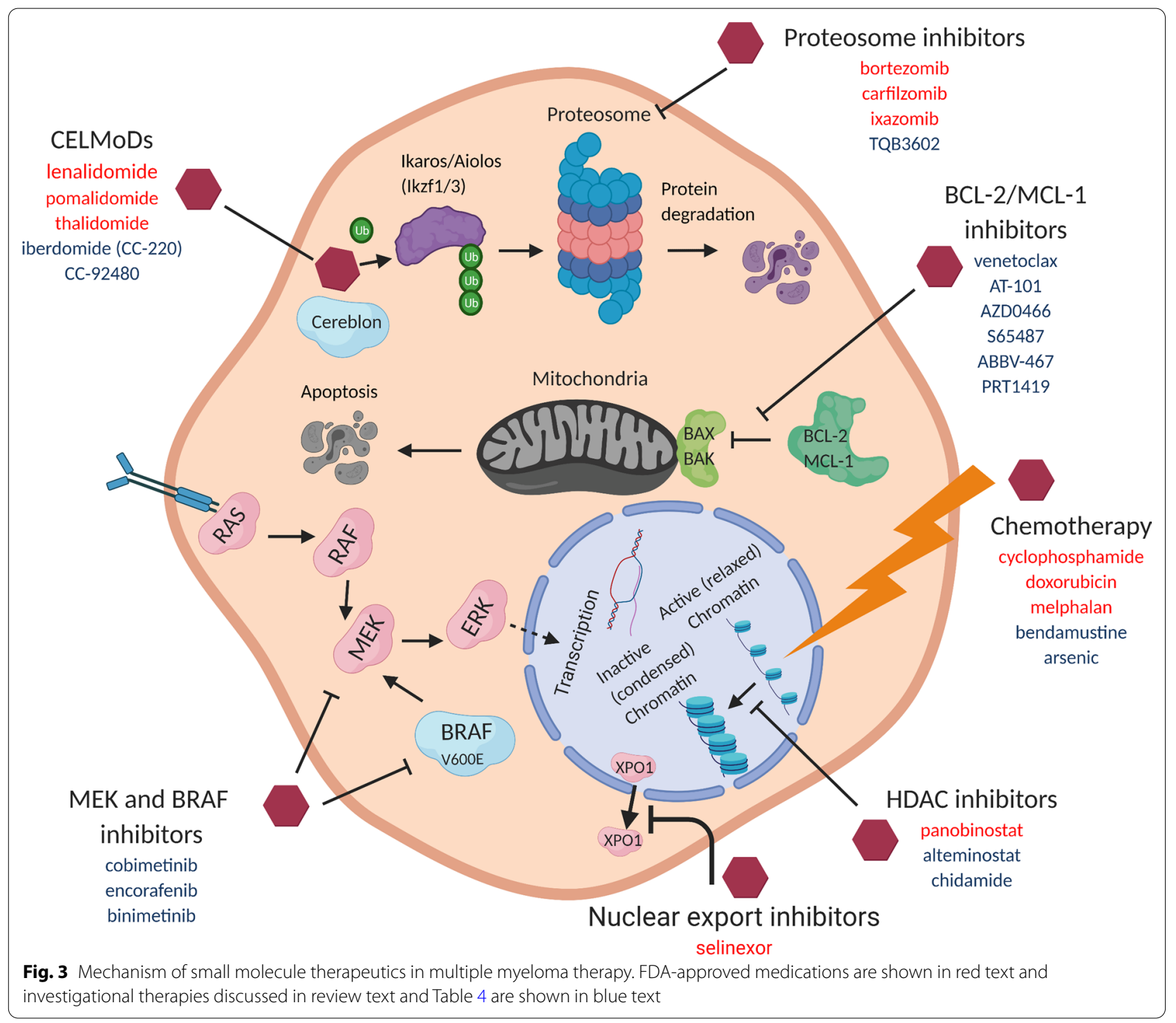

cyclin D1 overexpression in $t(11 ; 14)$ multiple myeloma patients (up to 20\%), venetoclax is increasingly being investigated as a therapeutic targeted agent in this patient population. Venetoclax trials in RRMM was halted due to findings from the Bellini trial with increased mortality seen in the venetoclax group, mostly due to an increased rate of infection [81].

Venetoclax was combined with Daratumumab in M15654 trial (NCT03314181, Phase 1/2, multiple countries) which enrolled 48 RRMM patients in two groups [82]. In Part 1 , patients with $t(11 ; 14)$ who received $\geq 1$ prior line of therapy (PI and an IMIDs) were treated with VenDd. In Part 2, patients irrespective of $t(11 ; 14)$ status, non-refractory to PIs and failed 1-3 prior lines of therapy were treated with VenDVd. Frequent Grade $\geq 3$ AEs in patients on VenDd were neutropenia (17\%), hypertension (12\%), fatigue and hyperglycemia ( $8 \%$ each), and in patients on VenDVd were insomnia (21\%), diarrhea and thrombocytopenia (8\% each). Eighteen patients had a serious AE (11 VenDd, 7 VenDVd), with pyrexia $(n=3)$ being most common. Median follow-up (VenDd/VenDVd) was 10 and 9 months. Overall response rate in VenDd/VenDVd was $96 \% / 92 \%$ and $96 \% / 79 \%$ had $\geq$ very good partial response rate. Median progression free survival and duration of response were not reached.

Novel Bcl-2 inhibitor AT-101 (NCT02697344, Phase 1, United States) enrolled 10 RRMM patients treated with median 2 prior lines of therapy in a safety and preliminary efficacy trial [27]. AT-101 is a pan BCL-2 inhibitor and the trial combined it with lenalidomide. ORR was $44 \%$ 
Table 5 Phase 1 and early phase 1 small molecule inhibitors/modulators for RRMM, as of December 31, 2020, with study start date after January 1, 2019

\begin{tabular}{|c|c|c|c|c|}
\hline Target pathway & Product name (NCT) & Study sponsor & Estimated enrollment & Country \\
\hline Adenosine-2A receptor & $\begin{array}{l}\text { Ciforadenant (CPI-444) } \\
\text { (NCT04280328) }\end{array}$ & Corvus & 28 & United States \\
\hline Arginase & INCB001158 (NCT03837509) & Incyte & 98 & United States, Germany, Spain \\
\hline $\begin{array}{l}\mathrm{BCl}-2 / \mathrm{BCl}-\mathrm{xL} \text { (apoptosis } \\
\text { regulator) }\end{array}$ & AZD0466 (NCT04214093) & AstraZeneca & 102 & United States \\
\hline $\mathrm{BCl}-2$ & S65487 (NCT03755154) & $\begin{array}{l}\text { Institut de Recherches Inter- } \\
\text { nationales Servier }\end{array}$ & 60 & $\begin{array}{l}\text { Australia, France, Spain, United } \\
\text { Kingdom }\end{array}$ \\
\hline BTK (Bruton's tyrosine kinase) & Ibrutinib (NCT03702725) & Alliance Foundation & 28 & United States \\
\hline $\begin{array}{l}\text { Cereblon E3 ubiquitin ligase } \\
\text { (CELMoD - protein homeo- } \\
\text { stasis) }\end{array}$ & CC-92480 (NCT03989414) & Celgene & 215 (includes NDMM) & $\begin{array}{l}\text { United States, Canada, Den- } \\
\text { mark, Finland, Spain, United } \\
\text { Kingdom }\end{array}$ \\
\hline $\begin{array}{l}\text { IL-15 receptor (cytokine } \\
\text { signaling) }\end{array}$ & NKTR-255 (NCT04136756) & Nektar & 87 & United States \\
\hline $\begin{array}{l}\text { IRF4 (lymphocyte transcrip- } \\
\text { tional factor) }\end{array}$ & ION251 (NCT04398485) & lonis & 80 & United States \\
\hline $\begin{array}{l}\text { JAK (Janus kinase/tyrosine } \\
\text { kinase) }\end{array}$ & Ruxolitinib (NCT03773107) & Incyte & 48 & United States \\
\hline $\begin{array}{l}\text { LMP7 (proteasome complex } \\
\text { subunit) }\end{array}$ & M3258 (NCT04075721) & EMD Serono & 48 & United States, France \\
\hline Mcl-1 (apoptosis control) & ABBV-467 (NCT04178902) & AbbVie & 54 & $\begin{array}{l}\text { United States, Australia, France, } \\
\text { Israel, Japan, Spain, Taiwan }\end{array}$ \\
\hline Mcl-1 & PRT1419 (NCT04543305) & Prelude & 36 & United States \\
\hline $\begin{array}{l}\text { NEDD8 (ubiquitin-like } \\
\text { protein) }\end{array}$ & Pevonedistat (NCT03770260) & National Cancer Institute & 66 & United States \\
\hline $\begin{array}{l}\text { p300/CBP (transcriptional } \\
\text { coactivating proteins) }\end{array}$ & CCS1477 (NCT04068597) & CellCentric & 90 & United Kingdom \\
\hline Proteasome inhibitor & TQB3602 (NCT04275583) & Chia Tai Tianqing & 40 & China \\
\hline RAD51 (DNA repair protein) & CYT-0851 (NCT03997968) & Cyteir & 165 & United States \\
\hline $\begin{array}{l}\text { S100A9 (regulation of } \\
\text { immune response and } \\
\text { inflammation) }\end{array}$ & Tasquinimod (NCT04405167) & University of Pennsylvania & 54 & United States \\
\hline $\begin{array}{l}\text { TIGIT (T and NK cell immune } \\
\text { receptor) }\end{array}$ & COM902 (NCT04354246) & Compugen & 45 & United States \\
\hline TIGIT & Tiragolumab (NCT04045028) & Genentech & 52 & United States, Korea \\
\hline Anti-TIGIT and anti-LAG & $\begin{array}{l}\text { BMS-986016 and BMS- } \\
986207 \text { (NCT04150965) }\end{array}$ & $\begin{array}{l}\text { Multiple Myeloma Research } \\
\text { Consortium }\end{array}$ & 104 & United States \\
\hline $\begin{array}{l}\text { TRAIL (tumor necrosis factor- } \\
\text { related apoptosis-inducing } \\
\text { ligand) }\end{array}$ & $\begin{array}{l}\text { Eftozanermin alfa (ABBV-621) } \\
\text { (NCT04570631) }\end{array}$ & AbbVie & 40 & $\begin{array}{l}\text { United States, France, German, } \\
\text { Italy, Japan, Spain }\end{array}$ \\
\hline $\begin{array}{l}\text { Specific targeted therapy } \\
\text { based on mutations uncov- } \\
\text { ered with genomic studies }\end{array}$ & MyDRUG (NCT03732703) & $\begin{array}{l}\text { Multiple Myeloma Research } \\
\text { Consortium }\end{array}$ & 228 & United States \\
\hline $\begin{array}{l}\text { Specific targeted therapy } \\
\text { based on mutations uncov- } \\
\text { ered with genomic studies }\end{array}$ & $\begin{array}{l}\text { SMMART PRIME } \\
\text { (NCT03878524) }\end{array}$ & $\begin{array}{l}\text { Oregon Health and Science } \\
\text { University }\end{array}$ & 40 & United States \\
\hline
\end{tabular}

in evaluable patients, and median PFS was 8.1 months. Dose-limiting toxicities included grade 4 febrile neutropenia and thrombocytopenia. Most common grade 3-4 AEs included neutropenia, leukopenia, and thrombocytopenia. No patients experienced TLS.

Finally, MCL-1 is another antiapoptotic member of the BCL-2 family of proteins. Similar to BCL-2, MCL-1 binds to pro-apoptotic proteins BAK and BAX, and MCL-1 inhibitors remove that regulation and induce apoptosis via the intrinsic mitochondrial pathway [83]. Several MCL-1 inhibitor trials are underway, with promising preclinical data demonstrating in vitro tumor cell death and in vivo tumor growth inhibition $[84,85]$. Thus far, phase 1 clinical trials are ongoing. 


\section{Histone deacetylase (HDAC) inhibitors}

The only HDAC inhibitor approved for multiple myeloma is panobinostat, approved in 2015 following the PANORAMA1 trial [86]. Panobinostat combined with bortezomib and dexamethasone achieved a median PFS of 12.0 months compared to 5.5 months in the placebo group. However, grade 3-4 AEs occurred in $96 \%$ of patients in the panobinostat group, compared to $82 \%$ in the placebo group. Panobinostat was ultimately approved with black box warnings for severe diarrhea $(68 \%$ in the panobinostat cohort and $25 \%$ being grade $3-4$, with $42 \%$ in the placebo group and 8\% being grade 3-4) and EKG changes (prolonged QTc).

Since panobinostat, research into other promising agents in the family of HDAC inhibitors has continued (Fig. 3). There are 18 defined HDACs which play crucial roles in histone deacetylation, an important epigenetic modification that activates DNA transcription and is implicated in neoplastic growth. HDAC inhibitors reduce the activity of aberrant myeloma cells by inducing histone hyperacetylation, leading to cell cycle arrest and apoptosis [87].

The alteminostat trial (NCT03150316, Phase 1, South Korea) has enrolled 10 RRMM patients treated with median of 2.5 prior lines of therapy in a trial designed to assess alteminostat in combination with lenalidomide and dexamethasone [28]. Alteminostat is a novel panHDAC inhibitor with significant in vitro growth inhibition of multiple myeloma cell lines, especially in reducing the secretion of interleukin 6 , which is associated with the proliferation of myeloma cells [88]. ORR was $70 \%$ in evaluable patients with $10 \% \mathrm{sCR}$, and median PFS was 7.7 months. Most common AEs included thrombocytopenia $(80 \%)$, neutropenia $(60 \%)$, and anemia $(50 \%)$. No serious AEs, including cardiac disorders, were reported. The most common grade 3-4 AEs were neutropenia (70\%), thrombocytopenia (60\%), and anemia (60\%).

The chidamide trial (NCT04025450, Phase 1, China) has enrolled 12 NDMM patients with high-risk characteristics in a clinical trial designed to assess chidamide in combination with bortezomib, lenalidomide, and dexamethasone [29]. Chidamide is a selective HDAC inhibitor targeting HDAC 1, 2, 3, and 10 which is currently approved in China for the treatment of peripheral $\mathrm{T}$ cell lymphomas [89]. Preclinical studies have indicated increased apoptosis and cell cycle arrest in treated myeloma cells [90]. In the clinical trial, ORR was $100 \%$ for evaluable patients, and $77 \%$ of patients obtained VGPR after one cycle. AEs included leukopenia, thrombocytopenia, and transaminase elevation. Grade 3-4 AEs were reported for thrombocytopenia and transaminase elevation. Two patients discontinued the study due to acute cardiac and acute renal failure.

In order to mitigate the toxicity associated with panHDAC inhibitors, preclinical studies have investigated selective HDAC6/8 inhibition (JBI-802, CVL608, CS3003) with demonstrable in vitro and in vivo myeloma growth inhibition [91-93]. These novel agents herald the arrival of more tailored approaches to HDAC inhibition in the future.

\section{Cereblon E3 ligase modulating drugs (CELMoD)}

Lenalidomide, pomalidomide, and thalidomide are immunomodulators of cereblon E3 ligase, an essential enzyme in the cellular protein homeostasis machinery [94]. Proteins recruited cereblon E3 ligase are tagged with chains of ubiquitin and subsequently digested by the proteasome. CELMoDs bind to the surface of cereblon and recruit transcription factors such as Ikaros (IKZF1) and Aiolos (IKZF3) which are overexpressed in myeloma cells. These transcription factors are then ubiquitinated and targeted for subsequent destruction, leading to eventual host cell death (Fig. 3). There are currently several CELMoDs under clinical investigation [95].

The CC-220-MM-001 trial (iberdomide, NCT02773030, Phase $1 / 2$, multiple countries) is a doseescalation trial combining iberdomide with different treatment combinations. Thus far, it has demonstrated a favorable safety profile when combined with dexamethasone [96]. 19 patients received iberdomide in combination with daratumumab and dexamethasone (IberDd, median 4 prior lines of therapy) and 21 patients received iberdomide in combination with bortezomib and dexamethasone (IberVd, median 6 prior lines of therapy) [30]. ORR was $35 \%$ with IberDd and 50\% with IberVd in evaluable patients. Median time to response was 4.1 and 4.9 weeks in both cohorts, respectively. Grade 3-4 AEs were reported in $78 \%$ with IberDd, most common being neutropenia (50\%) and anemia (22\%); 65\% of patients with IberVd, most common being neutropenia (20\%) and thrombocytopenia (20\%).

The CC-92480 trial (NCT03374085, Phase 1, multiple countries) enrolled RRMM patients in a first-in-human study to evaluate the biological and clinical effects of CC-92480 and dexamethasone in heavily pretreated multiple myeloma patients [31]. The authors reported that Ikaros and Aiolos dose-associated degradation with concurrent $\mathrm{T}$ cell proliferation. CC-92480 led to rapid and sustained decreases in serum free light chains, although gaps in drug administration led to rapid rebound of these markers. Other CELMoDs (KPG-818, BTX-PHM) are currently under investigation, with favorable preclinical data $[97,98]$. 


\section{MEK and BRAF inhibitors}

Given the prevalence of MAPK pathway mutations in over $50 \%$ of newly-diagnosed myeloma patients [99], a trial investigating cobimetinib (cobimetinib, NCT03312530, Phase 1/2, multiple countries) enrolled 49 RRMM patients with median 4 prior lines of therapy in studies investigating the efficacy of MEK inhibition alone and combined with venetoclax (BCL-2 inhibition) and atezolizumab (PD-L1 inhibition) [32]. ORR was $0 \%$ for cobimetinib alone $(\mathrm{C}), 27 \%$ for cobimetinib combined with venetoclax $(\mathrm{C}+\mathrm{V})$, and $29 \%$ for cobimetinib combined with venetoclax and atezolizumab $(\mathrm{C}+\mathrm{V}+\mathrm{A})$. Median duration of response was 11.5 months and 5.1 months for the $\mathrm{C}+\mathrm{V}$ and $\mathrm{C}+\mathrm{V}+\mathrm{A}$ arms, respectively. The most common adverse effects $(\mathrm{C} / \mathrm{C}+\mathrm{V} / \mathrm{C}+\mathrm{V}+\mathrm{A})$ were diarrhea $(33 \% / 82 \% / 91 \%)$, nausea $(17 \% / 50 \% / 67 \%)$, and anemia $(17 \% / 46 \% / 57 \%)$. Two cases of tumor lysis syndrome were reported, and treatment discontinuation were similar across the three arms at $14-18 \%$.

Another trial using encorafenib and binimetinib (encorafenib and binimetinib, NCT02834364, Phase 2, Germany) enrolled 12 patients with median 5 prior lines of therapy in a study investigating BRAF and MEK inhibition in RRMM patients with BRAF V600E mutation; activating mutations of BRAF are found in up to $10 \%$ of RRMM patients[33, 100]. ORR was $82 \%$ with $27 \%$ of evaluable patients reaching CR. PFS assessment is still in progress, but duration of response exceeding 1 year was observed. Most common grade 3-4 AEs included anemia (25\%), hypertension (25\%), and thrombocytopenia (17\%).

\section{Other investigational therapies}

Other current investigational therapies include oncolytic targeted vaccines [101-104], enhancements to existing $\mathrm{T}$ cell-directed therapies [105], and other types of adoptive cell therapy aside from CAR-T cells $[106,107]$. Trials studying chemotherapy agents such as bendamustine and arsenic have decreased in recent years in favor of targeted therapeutics [108, 109], although there are ongoing efforts to examine the efficacy of these agents in specialized populations [110-112].

Melphalan flufenamide (Melflufen), a peptidase enhanced cytotoxic derivative of melphalan with targeted delivery of melphalan via membrane bound aminopeptidase N (APN or AD13) [113], has demonstrated favorable in vitro and ex vivo effects on high risk multiple myeloma cell lines with del17p and TP53 mutations [114]. Melphalan flufenamide combined with dexamethasone was approved by the FDA in February 2021 based on HORIZON trial (NCT02963493) in RRMM patients who failed at least four prior lines of therapy [115].

\section{Conclusion}

Immunotherapy has taken central stage thanks to relentless technological advancement and drug development. CAR-T/NK, BITEs, and ADCs, followed by novel small molecule targeted inhibitors/modulators, have shifted the multiple myeloma therapeutic paradigm. The ongoing trials with these novel agents offer patients various avenues of potential promising treatment options. Nevertheless, we are still facing many challenges ahead in RRMM management: how to achieve sustained deep remission, how to sequence and combine agents of different mechanisms of action, how to better manage and even prevent adverse effects, and how to improve and optimize convenience of drug administrations to patients.

Furthermore, drug resistance and immune escape are particularly complicated and challenging in the novel immunotherapies in RRMM, thus calling for more thought-provoking ideas to study mechanistic biology in basic and translational research [116, 117], better designed clinical trials to enrich patient populations stratified by meaningful biomarkers, and consolidated efforts to conduct high quality trials to generate practice changing data that can benefit our myeloma patients.

The financial costs associated with these novel therapies is another important issue for consideration: for instance, whether society, health system and patients can afford the expense of treatments such as CAR-T. However, patients can benefit from CAR-T as a promising therapy and enjoy a treatment break from chronic therapy $[118,119]$. Treatment de-escalation in subset of the patients who achieved sustained deep response can not only spare patients from unnecessary long term drug toxicity, but also significantly reduce costs.

In summary, the advent of the novel myeloma therapeutic landscape will continue to evolve, paving the way to a new era of highly individualized treatment regimens and sophisticated disease burden assessment, moving the needle ever closer to an eventual cure.

\section{Acknowledgements}

Figures 1 and 3 were created with Biorender.com

Authors' contributions

CTS and JCY both drafted and edited the work. Both authors read and approved the final manuscript.

Funding

CTS is supported by a National Institutes of Health T32 Grant (T32-CA-236621).

Availability of data and materials

Not applicable.

\section{Declarations}

Ethics approval and consent to participate Not applicable. 


\section{Consent for publication}

Not applicable.

\section{Competing interests}

CTS does not have any competing interests to declare. JCY declares research funding from Janssen, GSK, Nektar, Celgene, Takeda, Karyopharm, Sanofi, Multiple Myeloma Research Foundation, CARsgen.

\section{Author details \\ ${ }^{1}$ Department of Internal Medicine, University of Michigan, Ann Arbor, MI 48109, USA. ${ }^{2}$ Rogel Cancer Center, University of Michigan, Ann Arbor, MI 48109, USA}

\section{Received: 7 February 2021 Accepted: 9 June 2021}

Published online: 23 July 2021

\section{References}

1. Mikhael J, Ismaila N, Cheung MC, Costello C, Dhodapkar MV, Kumar S, Lacy M, Lipe B, Little RF, Nikonova A, et al. Treatment of multiple myeloma: ASCO and CCO joint clinical practice guideline. J Clin Oncol. 2019;37(14):1228-63.

2. van Beurden-Tan CHY, Franken MG, Blommestein HM, Uyl-de Groot CA, Sonneveld P. Systematic literature review and network meta-analysis of treatment outcomes in relapsed and/or refractory multiple myeloma. J Clin Oncol. 2017;35(12):1312-9.

3. Ye CJ, Chen J, Liu G, Heng HH. Somatic genomic mosaicism in multiple myeloma. Front Genet. 2020;11:388.

4. Heng J, Heng HH. Genome chaos: creating new genomic information essential for cancer macroevolution. Semin Cancer Biol. 2020. https:// doi.org/10.1016/j.semcancer.2020.11.003.

5. Lonial S, Lee HC, Badros A, Trudel S, Nooka AK, Chari A, Abdallah AO, Callander N, Lendvai N, Sborov D, et al. Belantamab mafodotin for relapsed or refractory multiple myeloma (DREAMM-2): a two-arm, randomised, open-label, phase 2 study. Lancet Oncol. 2020;21(2):207-21.

6. Munshi NC, Anderson LD, Shah N, Madduri D, Berdeja J, Lonial S, Raje $\mathrm{N}$, Lin Y, Siegel D, Oriol A, et al. Idecabtagene vicleucel in relapsed and refractory multiple myeloma. N Engl J Med. 2021;384(8):705-16.

7. Madduri D, Berdeja JG, Usmani SZ, Jakubowiak A, Agha M, Cohen AD, Stewart AK, Hari P, Htut M, O'Donnell E, et al. CARTITUDE-1: phase $1 \mathrm{~b} / 2$ study of ciltacabtagene autoleucel, a B-cell maturation antigendirected chimeric antigen receptor $T$ cell therapy, in relapsed/refractory multiple myeloma. Blood. 2020;136(Supplement 1):22-5.

8. Alsina M, Shah N, Raje NS, Jagannath S, Madduri D, Kaufman JL, Siegel DS, Munshi NC, Rosenblatt J, Lin Y, et al. Updated results from the phase I CRB-402 study of anti-Bcma CAR-T cell therapy bb21217 in patients with relapsed and refractory multiple myeloma: correlation of expansion and duration of response with T cell phenotypes. Blood. 2020;136(Supplement 1):25-6.

9. Nishihori T, Kaufman JL, Hoffman JE, Blouch K, Pandit S, Butler E, Jain A, Wu Y, DeYoung MP, Hasan AN, et al. Open-label pilot study of genetically engineered NY-ESO-1 specific T cells (GSK3377794) alone or in combination with pembrolizumab in relapsed and refractory multiple myeloma. Blood. 2019;134(Supplement_1):3134-3134.

10. Jiang H, Dong B, Gao L, Liu L, Ge J, He A, Du J Jr, Li L, Lu J, Chen X, et al. Clinical results of a multicenter study of the first-in-human dual BCMA and CD19 targeted novel platform fast CAR-T cell therapy for patients with relapsed/refractory multiple myeloma. Blood. 2020;136(Supplement 1):25-6.

11. Li C, Mei H, Hu Y, Guo T, Liu L, Jiang H, Tang L, Wu Y, Ai L, Deng J, et al. A bispecific CAR-T cell therapy targeting Bcma and CD38 for relapsed/ refractory multiple myeloma: updated results from a phase 1 doseclimbing trial. Blood. 2019;134(Supplement_1):930-930.

12. Mailankody S, Matous JV, Liedtke M, Sidana S, Malik S, Nath R, Oluwole OO, Karski EE, Lovelace W, Zhou X, et al. Universal: an allogeneic first-inhuman study of the anti-Bcma ALLO-715 and the anti-CD52 ALLO-647 in relapsed/refractory multiple myeloma. Blood. 2020;136(Supplement 1):24-5.

13. Garfall AL, Usmani SZ, Mateos M-V, Nahi H, van de Donk NWCJ, SanMiguel JF, Oriol Rocafiguera A, Rosinol L, Chari A, Bhutani M, et al.
Updated phase 1 results of teclistamab, a B-cell maturation antigen (BCMA) x CD3 bispecific antibody, in relapsed and/or refractory multiple myeloma (RRMM). Blood. 2020;136(Supplement 1):27-27.

14. Costa LJ, Wong SW, Bermúdez A, de la Rubia J, Mateos M-V, Ocio EM, Rodríguez-Otero P, San-Miguel J, Li S, Sarmiento R, et al. First clinical study of the B-cell maturation antigen (BCMA) $2+1$ T cell engager (TCE) CC-93269 in patients (Pts) with relapsed/refractory multiple myeloma (RRMM): interim results of a phase 1 multicenter trial. Blood. 2019;134(Supplement_1):143-143.

15. Lesokhin AM, Levy MY, Dalovisio AP, Bahlis NJ, Solh M, Sebag M, Jakubowiak A, Jethava YS, Costello CL, Chu MP, et al. Preliminary safety, efficacy, pharmacokinetics, and pharmacodynamics of subcutaneously (SC) administered PF-06863135, a B-cell maturation antigen (BCMA)CD3 bispecific antibody, in patients with relapsed/refractory multiple myeloma (RRMM). Blood. 2020;136(Supplement 1):8-9.

16. Rodriguez C, D'Souza A, Shah N, Voorhees PM, Buelow B, Vij R, Kumar SK. Initial results of a phase I study of TNB-383B, a BCMA x CD3 bispecific T-cell redirecting antibody, in Relapsed/refractory multiple myeloma. Blood. 2020;136(Supplement 1):43-4.

17. Madduri D, Rosko A, Brayer J, Zonder J, Bensinger WI, Li J, Xu L, Adriaens L, Chokshi D, Zhang W, et al. REGN5458, a BCMA x CD3 bispecific monoclonal antibody, induces deep and durable responses in patients with relapsed/refractory multiple myeloma (RRMM). Blood. 2020;136(Supplement 1):41-2.

18. Chari A, Berdeja JG, Oriol A, van de Donk NWCJ, Rodriguez P, Askari E, Mateos M-V, Minnema MC, Verona R, Girgis S, et al. A phase 1, first-inhuman study of talquetamab, a $\mathrm{G}$ protein-coupled receptor family $\mathrm{C}$ group 5 member D (GPRC5D) x CD3 bispecific antibody, in patients with relapsed and/or refractory multiple myeloma (RRMM). Blood. 2020;136(Supplement 1):40-1.

19. Cohen AD, Harrison SJ, Krishnan A, Fonseca R, Forsberg PA, Spencer A, Berdeja JG, Laubach JP, Li M, Choeurng V, et al. Initial clinical activity and safety of BFCR4350A, a FCRH5/CD3 T-cell-engaging bispecific antibody, in relapsed/refractory multiple myeloma. Blood. 2020;136(Supplement 1):42-3.

20. Kumar SK, Migkou M, Bhutani M, Spencer A, Ailawadhi S, Kalff A, Walcott F, Pore N, Gibson D, Wang F, et al. Phase 1, first-in-human study of MEDI2228, a BCMA-targeted ADC in patients with relapsed/refractory multiple myeloma. Blood. 2020;136(Supplement 1):26-7.

21. Kumar SK, Cornell RF, Landgren O, Ailawadhi S, Higgins JP, Willert EK, Waltzman R, Lin J, Zhang Y, Lublinsky AR, et al. A phase 1 first-in-human study of the anti-CD38 dimeric fusion protein TAK-169 for the treatment of patients (pts) with relapsed or refractory multiple myeloma (RRMM) who are proteasome inhibitor (PI)- and immunomodulatory drug (IMiD)-refractory, including Pts relapsed/refractory (R/R) or naïve to daratumumab (dara). Blood. 2019;134(Supplement_1):1867-1867.

22. Krishnan AY, Patel KK, Hari P, Jagannath S, Niesvizky R, Silbermann RW, Berg DT, Li Q, Allikmets K, Stockerl-Goldstein K. A phase lb study of TAK-079, an investigational anti-CD38 monoclonal antibody (mAb) in patients with relapsed/ refractory multiple myeloma (RRMM): Preliminary results. J Clin Oncol. 2020;38(15_suppl):8539-8539.

23. Vogl DT, Kaufman JL, Holstein SA, Nadeem O, O'Donnell E, Suryanarayan K, Collins S, Parot X, Chaudhry M. TAK-573, an anti-CD38/ attenuated Ifna fusion protein, has clinical activity and modulates the Ifna receptor (IFNAR) pathway in patients with relapsed/refractory multiple myeloma. Blood. 2020;136(Supplement 1):37-8.

24. Virone-Oddos A, Kassem S, Diallo B, Tang A, Fournier A, El-Murr N, Carrie-Constantin N, Nicolazzi C, Arnould I, Avet-Loiseau H, et al. Abstract 2266: SAR442085, a next generation anti-CD38 antibody with enhanced antibody-dependent cellular cytotoxicity (ADCC) against multiple myeloma. Cancer Res. 2020;80(16 Supplement):2266-2266.

25. Bahlis N, Baz R, Harrison S, Quach H, Ho S-J, Vangsted AJ, Moreau P, Gibbs S, Salem AH, Ross JA, et al. First analysis from a phase 1/2 study of venetoclax in combination with daratumumab and dexamethasone, +/- Bortezomib, in patients with relapsed/refractory multiple myeloma. Blood. 2019;134(Supplement_1):925-925.

26. Kaufman JL, Gasparetto C, Schjesvold FH, Moreau P, Touzeau C, Facon T, Boise LH, Alzate S, Macartney T, Pesko J, et al. Phase I/II study evaluating the safety and efficacy of venetoclax in combination with dexamethasone as targeted therapy for patients with $\mathrm{t}(11 ; 14)$ relapsed/refractory multiple myeloma. Blood. 2019;134(Supplement 1):926-926. 
27. Ailawadhi S, Alegria VR, Ahmed S, Laplant B, Manna A, Parrondo R, Roy V, Sher T, Edwards B, Lanier S, et al. Phase I study of a novel BCl-2 inhibitor, at-101 in combination with lenalidomide and dexamethasone in patients with relapsed and/or refractory multiple myeloma (RRMM) Blood. 2019;134(Supplement_1):3137-3137.

28. Min CK, Kim K, Kim SJ, Yoon DH, Park S-S, Han S. A phase 1, open-label, multi-center study of alteminostat (CKD-581) in combination with lenalidomide and dexamethasone in patients with previously treated multiple myeloma (MM). Blood. 2019;134(Supplement_1):1847-1847.

29. Shang J, Yao W, Yan L, Shi X, Wang R, Yan S, Liu Y, Wu D, Cheng Cheng F. Initial safety and efficacy of dose-escalating HDACs inhibitor chidamide with VRD (Chi-VRD) treatment for newly-diagnosed high-risk transplant eligible multiple myeloma patients. Blood. 2019;134(Supplement_1):1855-1855.

30. van de Donk NWCJ, Popat R, Larsen J, Minnema MC, Jagannath S, Oriol A, Zonder J, Richardson PG, Rodriguez-Otero P, Badros AZ, et al. First results of iberdomide (IBER; CC-220) in combination with dexamethasone (DEX) and daratumumab (DARA) or bortezomib (BORT) in patients with relapsed/refractory multiple myeloma (RRMM). Blood. 2020;136(Supplement 1):16-7.

31. Wong L, Lamba M, Jiménez Nuñez MD, Bauer D, Richardson PG, Bahlis NJ, Vangsted AJ, Ramasamy K, Trudel S, Martínez-Lopez J, et al. Doseand schedule-dependent immunomodulatory effects of the novel celmod agent CC-92480 in patients with relapsed/refractory multiple myeloma. Blood. 2020;136(Supplement 1):47-8.

32. Schjesvold F, Ribrag V, Rodriguez-Otero P, Robak PJ, Hansson M, Hajek R, Amor AA, Martinez-López J, Onishi M, Gallo JD, et al. Safety and preliminary efficacy results from a phase $\mathrm{lb} / \mathrm{Il}$ study of cobimetinib as a single agent and in combination with venetoclax with or without atezolizumab in patients with relapsed/refractory multiple myeloma. Blood. 2020;136(Supplement 1):45-6.

33. Raab MS, Giesen N, Scheid C, Besemer B, Miah K, Benner A, Metzler I, Khandanpour C, Seidel-Glaetzer A, Trautmann-Grill K, et al. Safety and preliminary efficacy results from a phase II study evaluating combined BRAF and MEK inhibition in relapsed/refractory multiple myeloma (rrMM) patients with activating BRAF V600E mutations: the GMMGBirma trial. Blood. 2020;136(Supplement 1):44-5.

34. Ocio EM, Efebera YA, Hájek R, Granell M, Maisnar V, Straub J, Eveillard J-R, Karlin L, Ribrag V, Mateos M-V, et al. ANCHOR (OP-104): melflufen plus dexamethasone (dex) and daratumumab (dara) or bortezomib (BTZ) in relapsed/refractory multiple myeloma (RRMM) refractory to an IMiD and/or a proteasome inhibitor (PI) — updated efficacy and safety. Blood. 2020;136(Supplement 1):9-10.

35. Mateos M-V, Oriol A, Larocca A, Blade J, Cavo M, Otero PR, Leleu X, Hiemenz JW, Hassoun H, Touzeau C, et al. HORIZON (OP-106): An exploratory analysis of time-to-next treatment (TTNT) in patients (pts) with relapsed/refractory multiple myeloma (RRMM) who received melflufen plus dexamethasone (dex). J Clin Oncol. 2020;38(15_suppl):e20570-e20570.

36. Gagelmann N, Riecken K, Wolschke C, Berger C, Ayuk FA, Fehse B, Kröger N. Development of CAR-T cell therapies for multiple myeloma. Leukemia. 2020;34(9):2317-32.

37. Zhang $\mathrm{H}$, Zhao $\mathrm{P}$, Huang $\mathrm{H}$. Engineering better chimeric antigen receptor T cells. Exp Hematol Oncol. 2020;9(1):34.

38. Wang Z, Wu Z, Liu Y, Han W. New development in CAR-T cell therapy. J Hematol Oncol. 2017;10(1):53.

39. Yu S, Yi M, Qin S, Wu K. Next generation chimeric antigen receptor T cells: safety strategies to overcome toxicity. Mol Cancer. 2019;18(1):125.

40. Novak AJ, Darce JR, Arendt BK, Harder B, Henderson K, Kindsvogel W, Gross JA, Greipp PR, Jelinek DF. Expression of BCMA, TACI, and BAFF-R in multiple myeloma: a mechanism for growth and survival. Blood. 2004;103(2):689-94.

41. Yu B, Jiang T, Liu D. BCMA-targeted immunotherapy for multiple myeloma. J Hematol Oncol. 2020;13(1):125

42. Roex G, Timmers M, Wouters K, Campillo-Davo D, Flumens D, Schroyens W, Chu Y, Berneman ZN, Lion E, Luo F, et al. Safety and clinical efficacy of BCMA CAR-T-cell therapy in multiple myeloma. J Hematol Oncol. 2020;13(1):164.

43. Carpenter RO, Evbuomwan MO, Pittaluga S, Rose JJ, Raffeld M, Yang $\mathrm{S}$, Gress RE, Hakim FT, Kochenderfer JN. B-cell maturation antigen is a promising target for adoptive T-cell therapy of multiple myeloma. Clin Cancer Res. 2013;19(8):2048-60.

44. Wang B-Y, Zhao W-H, Liu J, Chen Y-X, Cao X-M, Yang Y, Zhang Y-L, Wang F-X, Zhang P-Y, Lei B, et al. Long-term follow-up of a phase 1, first-in-human open-label study of LCAR-B38M, a structurally differentiated chimeric antigen receptor $T$ (CAR-T) cell therapy targeting B-cell maturation antigen (BCMA), in patients (pts) with relapsed/refractory multiple myeloma (RRMM). Blood. 2019;134(Supplement_1):579-579.

45. Friedman KM, Garrett TE, Evans JW, Horton HM, Latimer HJ, Seidel SL, Horvath CJ, Morgan RA. Effective targeting of multiple B-cell maturation antigen-expressing hematological malignances by anti-B-cell maturation antigen chimeric antigen receptor T cells. Hum Gene Ther. 2018;29(5):585-601.

46. Lin Y, Raje NS, Berdeja JG, Siegel DS, Jagannath S, Madduri D, Liedtke M, Rosenblatt J, Maus MV, Massaro M, et al. Idecabtagene vicleucel (ide-cel, bb2121), a BCMA-directed CART cell therapy, in patients with relapsed and refractory multiple myeloma: updated results from phase 1 CRB-401 study. Blood. 2020;136(Supplement 1):26-7.

47. Timmers M, Roex G, Wang Y, Campillo-Davo D, Van Tendeloo VFI, Chu Y, Berneman ZN, Luo F, Van Acker HH, Anguille S. Chimeric antigen receptor-modified $\mathrm{T}$ cell therapy in multiple myeloma: beyond $\mathrm{B}$ cell maturation antigen. Front Immunol. 2019;10:1613.

48. Thomas R, Al-Khadairi G, Roelands J, Hendrickx W, Dermime S, Bedognetti D, Decock J. NY-ESO-1 based immunotherapy of cancer: current perspectives. Front Immunol. 2018;9:947.

49. Rapoport A, Hoffman JE, Kaufman JL, Blouch K, Butler E, Deyoung MP, Farsaci B, Hasan AN, Holmes AP, Huff A, et al. Open-label pilot study of genetically engineered NY-ESO-1-specific t cells (GSK3377794) alone or in combination with pembrolizumab in relapsed/refractory multiple myeloma. J Clin Oncol. 2020;38(15_suppl):TPS8555-TPS8555.

50. Kang L, Zhang J, Li M, Xu N, Qi W, Tan J, Lou X, Yu Z, Sun J, Wang Z, et al. Characterization of novel dual tandem CD19/BCMA chimeric antigen receptor T cells to potentially treat multiple myeloma. Biomark Res. 2020;8:14.

51. Graham C, Jozwik A, Pepper A, Benjamin R. Allogeneic CAR-T cells: More than ease of access? Cells. 2018;7(10):155.

52. Liu D, Zhao J, Song Y. Engineering switchable and programmable universal CARs for CART therapy. J Hematol Oncol. 2019;12(1):69.

53. Metelo AM, Walker I, Jozwik A, Graham C, Attwood C, Sanchez K, Dunlop A, Cuthill K, Rice C, Streetly M, et al. Allogeneic anti-Bcma CAR-T cells show tumour specific killing against primary multiple myeloma cells from different genomic sub-groups. Blood. 2019;134(Supplement_1):1834-1834.

54. Xia AL, He QF, Wang JC, Zhu J, Sha YQ, Sun B, Lu XJ. Applications and advances of CRISPR-Cas9 in cancer immunotherapy. J Med Genet. 2019:56(1):4-9.

55. Bachanova V, Maakaron J, McKenna DH, Cao Q, DeFor TE, He F, Janakiram M, Wangen R, Cayci Z, Grzywacz B, et al. Results of a phase 1 trial of Gda-201, nicotinamide-expanded allogeneic natural killer (NK) Cells in patients with refractory non-hodgkin lymphoma (NHL) and multiple myeloma. Blood. 2020;136(Supplement 1):6-6.

56. Topp MS, Gökbuget N, Zugmaier G, Klappers P, Stelljes M, Neumann S, Viardot A, Marks R, Diedrich H, Faul C, et al. Phase II trial of the antiCD19 bispecific T cell-engager blinatumomab shows hematologic and molecular remissions in patients with relapsed or refractory B-precursor acute lymphoblastic leukemia. J Clin Oncol. 2014;32(36):4134-40.

57. Brinkmann U, Kontermann RE. The making of bispecific antibodies. MAbs. 2017:9(2):182-212.

58. Shah N, Chari A, Scott E, Mezzi K, Usmani SZ. B-cell maturation antigen (BCMA) in multiple myeloma: rationale for targeting and current therapeutic approaches. Leukemia. 2020;34(4):985-1005.

59. Trudel S, Lendvai N, Popat R, Voorhees PM, Reeves B, Libby EN, Richardson PG, Anderson LD, Sutherland HJ, Yong K, et al. Targeting B-cell maturation antigen with GSK2857916 antibody-drug conjugate in relapsed or refractory multiple myeloma (BMA117159): a dose escalation and expansion phase 1 trial. Lancet Oncol. 2018;19(12):1641-53.

60. Sherbenou DW, Aftab BT, Su Y, Behrens CR, Wiita A, Logan AC, AcostaAlvear D, Hann BC, Walter P, Shuman MA, et al. Antibody-drug conjugate targeting CD46 eliminates multiple myeloma cells. J Clin Investig. 2016;126(12):4640-53. 
61. Seckinger A, Delgado JA, Moser S, Moreno L, Neuber B, Grab A, Lipp $\mathrm{S}$, Merino J, Prosper F, Emde M, et al. Target expression, generation, preclinical activity, and pharmacokinetics of the BCMA-T cell bispecific antibody EM801 for multiple myeloma treatment. Cancer Cell. 2017;31(3):396-410

62. Smith EL, Harrington K, Staehr M, Masakayan R, Jones J, Long TJ, Ng KY, Ghoddusi M, Purdon TJ, Wang X, et al. GPRC5D is a target for the immunotherapy of multiple myeloma with rationally designed CART cells. Sci Transl Med. 2019;11(485):eaau7746.

63. Ovacik AM, Li J, Lemper M, Danilenko D, Stagg N, Mathieu M, Ellerman D, Gupta V, Kalia N, Nguy T, et al. Single cell-produced and in vitroassembled anti-FcRH5/CD3 T-cell dependent bispecific antibodies have similar in vitro and in vivo properties. MAbs. 2019;11(2):422-33.

64. Beck A, Goetsch L, Dumontet C, Corvaïa N. Strategies and challenges for the next generation of antibody-drug conjugates. Nat Rev Drug Discov. 2017;16(5):315-37.

65. Yu B, Liu D. Antibody-drug conjugates in clinical trials for lymphoid malignancies and multiple myeloma. J Hematol Oncol. 2019;12(1):94.

66. Chauhan D, Singh AV, Brahmandam M, Carrasco R, Bandi M, Hideshima T, Bianchi G, Podar K, Tai YT, Mitsiades C, et al. Functional interaction of plasmacytoid dendritic cells with multiple myeloma cells: a therapeutic target. Cancer Cell. 2009;16(4):309-23.

67. Iberg A, Cornelison GL, Howard C, Robinson GL, Zhao J, Ramos HJ, Willert EK. Abstract 539: novel engineered toxin bodies targeting SLAMF7 (CS1). Cancer Res. 2020;80(16 Supplement):539-539.

68. Richardson PG, Htut M, Gasparetto C, Zonder JA, Martin TG III, Chen J, Brooks C, McDonald P, Rupprecht N, Wysowskyj H, et al. Results from phase $1 / 2$ trial of tagraxofusp in combination with pomalidomide and dexamethasone in relapsed or refractory multiple myeloma. Blood. 2019;134(Supplement_1):3145-3145.

69. Pemmaraju N, Lane AA, Sweet KL, Stein AS, Vasu S, Blum W, Rizzieri DA, Wang ES, Duvic M, Sloan JM, et al. Tagraxofusp in blastic plasmacytoid dendritic-cell neoplasm. N Engl J Med. 2019;380(17):1628-37.

70. Strassz A, Raab MS, Orlowski RZ, Kulke M, Schiedner G, Pahl A. A first in human study planned to evaluate Hdp-101, an anti-BCMA amanitin antibody-drug conjugate with a new payload and a new mode of action, in multiple myeloma. Blood. 2020;136(Supplement 1):34-34.

71. Pahl A, Lutz C, Hechler T. Amanitins and their development as a payload for antibody-drug conjugates. Drug Discov Today Technol. 2018;30:85-9.

72. Figueroa-Vazquez V, Ko J, Breunig C, Baumann A, Giesen N, Pálfi A, Müller C, Lutz C, Hechler T, Kulke M, et al. HDP-101, anti-BCMA antibody-drug conjugate, safely delivers amanitin to induce cell death in proliferating and resting multiple myeloma cells. Mol Cancer Ther. 2020;20:367-78.

73. Mateos MV, Dimopoulos MA, Cavo M, Suzuki K, Jakubowiak A, Knop S, Doyen C, Lucio P, Nagy Z, Kaplan P, et al. Daratumumab plus bortezomib, melphalan, and prednisone for untreated myeloma. N Engl J Med. 2018;378(6):518-28.

74. Fedyk ER, Zhao L, Koch A, Smithson G, Estevam J, Chen G, Lahu G, Roepcke S, Lin J, Mclean L. Safety, tolerability, pharmacokinetics and pharmacodynamics of the anti-CD38 cytolytic antibody TAK-079 in healthy subjects. Br J Clin Pharmacol. 2020;86(7):1314-25.

75. Matlung HL, Szilagyi K, Barclay NA, van den Berg TK. The CD47-SIRPa signaling axis as an innate immune checkpoint in cancer. Immunol Rev. 2017;276(1):145-64

76. Richards J, Bouchlaka MN, Puro RJ, Capoccia BJ, Hiebsch RR, Donio MJ, Wilson WC, Chakraborty P, Sung V, Pereira DS. Highly differentiated antiCD47 antibody, AO-176, potently inhibits hematologic malignancies alone and in combination. Blood. 2019;134(Supplement_1):1844-1844.

77. Wilson WC, Richards J, Puro RJ, Andrejeva G, Capoccia BJ, Donio MJ, Hiebsch RR, Chakraborty P, Sung V, Pereira DS. AO-176, a highly differentiated clinical stage anti-CD47 antibody, exerts potent anti-tumor activity in preclinical models of multiple myeloma as a single agent and in combination with approved therapeutics. Blood. 2020;136(Supplement 1):3-4.

78. Chari A, Vogl DT, Gavriatopoulou M, Nooka AK, Yee AJ, Huff CA, Moreau P, Dingli D, Cole C, Lonial S, et al. Oral selinexor-dexamethasone for triple-class refractory multiple myeloma. N Engl J Med. 2019;381(8):727-38
79. Kumar S, Kaufman JL, Gasparetto C, Mikhael J, Vij R, Pegourie B, Benboubker L, Facon T, Amiot M, Moreau P, et al. Efficacy of venetoclax as targeted therapy for relapsed/refractory $\mathrm{t}(11 ; 14)$ multiple myeloma. Blood. 2017;130(22):2401-9.

80. Moreau P, Chanan-Khan A, Roberts AW, Agarwal AB, Facon T, Kumar S, Touzeau C, Punnoose EA, Cordero J, Munasinghe W, et al. Promising efficacy and acceptable safety of venetoclax plus bortezomib and dexamethasone in relapsed/refractory MM. Blood. 2017;130(22):2392-400.

81. Kumar SK, Harrison SJ, Cavo M, de la Rubia J, Popat R, Gasparetto C, Hungria V, Salwender H, Suzuki K, Kim I, et al. Venetoclax or placebo in combination with bortezomib and dexamethasone in patients with relapsed or refractory multiple myeloma (BELLINI): a randomised, double-blind, multicentre, phase 3 trial. Lancet Oncol. 2020;21(12):1630-42.

82. Kaufman JL, Baz RC, Harrison SJ, Quach H, Ho S-J, Vangsted AJ, Moreau P, Gibbs SD, Salem AH, Coppola S, et al. Updated analysis of a phase I/II study of venetoclax in combination with daratumumab and dexamethasone, +/- bortezomib, in patients with relapsed/refractory multiple myeloma. J Clin Oncol. 2020;38(15_suppl):8511-8511.

83. Xiang $W$, Yang CY, Bai L. MCL-1 inhibition in cancer treatment. Onco Targets Ther. 2018;11:7301-14.

84. Caenepeel S, Karen R, Belmontes B, Verlinsky A, Tan H, Yang Y, Chen X, Li K, Allen J, Wahlstrom J, et al. Abstract 6218: Discovery and preclinical evaluation of AMG 397, a potent, selective and orally bioavailable MCL1 inhibitor. Cancer Res. 2020;80(16 Supplement):6218-6218.

85. Chen J, Wu C, Jiao L, Zhao L, Zhou Y, Li D, Tang G, Gu S, Deng J, Wang G, et al. Abstract 73: development of APG-3526 as a novel and highly efficacious MCL-1 inhibitor. Cancer Res. 2020;80(16 Supplement):73-73.

86. San-Miguel JF, Hungria VT, Yoon SS, Beksac M, Dimopoulos MA, Elghandour A, Jedrzejczak WW, Günther A, Nakorn TN, Siritanaratkul N, et al. Panobinostat plus bortezomib and dexamethasone versus placebo plus bortezomib and dexamethasone in patients with relapsed or relapsed and refractory multiple myeloma: a multicentre, randomised, double-blind phase 3 trial. Lancet Oncol. 2014;15(11):1195-206.

87. Cengiz Seval G, Beksac M. A comparative safety review of histone deacetylase inhibitors for the treatment of myeloma. Expert Opin Drug Saf. 2019;18(7):563-71.

88. Cho H, Yoon DH, Kim KP, Bae KS, Kim WS, Eom HS, Kim JS, Hong JY, Kim SJ, Lee H, et al. Phase I study of CKD-581, a pan-histone deacetylase inhibitor, in patients with lymphoma or multiple myeloma refractory to standard therapy. Investig New Drugs. 2018;36(5):877-85.

89. Shi Y, Jia B, Xu W, Li W, Liu T, Liu P, Zhao W, Zhang H, Sun X, Yang H, et al. Chidamide in relapsed or refractory peripheral $T$ cell lymphoma: a multicenter real-world study in China. J Hematol Oncol. 2017;10(1):69.

90. Yuan XG, Huang YR, Yu T, Jiang HW, XuY, Zhao XY. Chidamide, a histone deacetylase inhibitor, induces growth arrest and apoptosis in multiple myeloma cells in a caspase-dependent manner. Oncol Lett. 2019;18(1):411-9.

91. Sivanandhan D, Rajagopal S, Nair S, Basavaprabhu B, Dhkar R, Viswakarma S, Siddiqui A, Zainuddin M, Rudresh G, Daram P, et al. Abstract 1756: JBI-802 novel dual inhibitor of LSD1-HDAC6 for treatment of cancer. Cancer Res. 2020;80(16 Supplement):1756-1756.

92. Li Z, Cheng Y, Shen X, Wang Y. Abstract 513: preclinical evaluation of novel HDAC6 selective inhibitors CVL608 with potent in vitro and in vivo profiles in tumors. Cancer Res. 2020;80(16 Supplement):513-513.

93. Li Z, Ren Z, Ma J, Tang L, Lu L, Zhu Y, Wu Y, Liu T, Zhang J, Bao Y, et al. Abstract 4441: CS3003, an HDAC6-selective inhibitor, improves antiPD-1 immune checkpoint blockade therapy efficacy. Cancer Res. 2020;80(16 Supplement):4441-4441.

94. Chamberlain PP, Hamann LG. Development of targeted protein degradation therapeutics. Nat Chem Biol. 2019;15(10):937-44.

95. Gao S, Wang S, Song Y. Novel immunomodulatory drugs and neosubstrates. Biomark Res. 2020;8:2.

96. Lonial S, Amatangelo M, Popat R, Minnema MC, Zonder JA, Larsen J, Oriol Rocafiguera A, Campagnaro EL, Rodriguez Otero P, Badros AZ, et al. Translational and clinical evidence of a differentiated profile for the novel CELMoD, iberdomide (CC-220). Blood. 2019;134(Supplement_1):3119-3119.

97. Ge C, Liao B, Zhang L. Abstract 6367: KPG-818, a novel cereblon modulator, inhibits hematological malignancies in preclinical models. Cancer Res. 2020;80(16 Supplement):6367-6367. 
98. Chourasia AH, Fung L, Pasis A, McElwee B, Schoolmeesters A, Richard N, Lam I, Torres E, Erdman P, Sullivan R, et al. Abstract 1963: Targeting hematological malignancies with two functionally and mechanistically distinct classes of cereblon mediated protein homeostatic modulators. Cancer Res. 2020;80(16 Supplement):1963-1963.

99. Heuck CJ, Jethava Y, Khan R, van Rhee F, Zangari M, Chavan S, Robbins K, Miller SE, Matin A, Mohan M, et al. Inhibiting MEK in MAPK pathwayactivated myeloma. Leukemia. 2016;30(4):976-80.

100. Robiou du Pont S, Cleynen A, Fontan C, Attal M, Munshi N, Corre J, Avet-Loiseau H. Genomics of multiple myeloma. J Clin Oncol. 2017;35(9):963-7.

101. Packiriswamy N, Upreti D, Zhou Y, Khan R, Miller A, Diaz RM, Rooney CM, Dispenzieri A, Peng KW, Russell SJ. Oncolytic measles virus therapy enhances tumor antigen-specific T-cell responses in patients with multiple myeloma. Leukemia. 2020;34:3310-22.

102. Wang H, Huang W, Gao H, Liu TT. NY-ESO-1 Protein vaccine combining alum, $\mathrm{CpG} O \mathrm{ODN}$, and $\mathrm{HH} 2$ complex adjuvant induces protective and therapeutic anti-tumor responses in murine multiple myeloma. Onco Targets Ther. 2020;13:8069-77.

103. Bae J, Song W, Smith R, Daley J, Tai YT, Anderson KC, Munshi NC. A novel immunogenic CS1-specific peptide inducing antigen-specific cytotoxic T lymphocytes targeting multiple myeloma. Br J Haematol. 2012;157(6):687-701.

104. Cook J, Peng K-W, Ginos BF, Dueck AC, Giers M, Packiriswamy N, Brunton B, Patnaik MM, Witzig TE, Buadi FK, et al. Phase I trial of systemic administration of vesicular stomatitis virus genetically engineered to express NIS and human interferon beta, in patients with relapsed or refractory multiple myeloma (MM), acute myeloid leukemia (AML), and T-cell neoplasms (TCL). Blood. 2020;136(Supplement 1):7-8.

105. Perica K, De León MA, Durai M, Chiu YL, Bieler JG, Sibener L, Niemöller M, Assenmacher M, Richter A, Edidin M, et al. Nanoscale artificial antigen presenting cells for $T$ cell immunotherapy. Nanomedicine. 2014;10(1):119-29.

106. Vallet S, Pecherstorfer M, Podar K. Adoptive cell therapy in multiple Myeloma. Expert Opin Biol Ther. 2017;17(12):1511-22.

107. Goodridge JP, Bjordahl R, Mahmood S, Reiser J, Gaidarova S, Blum R, Cichocki F, Chu H-Y, Bonello G, Lee T, et al. FT576: multi-specific offthe-shelf CAR-NK cell therapy engineered for enhanced persistence, avoidance of self-fratricide and optimized mab combination therapy to prevent antigenic escape and elicit a deep and durable response in multiple myeloma. Blood. 2020;136(Supplement 1):4-5.

108. Li X, Sun WJ. The clinical activity of arsenic trioxide, ascorbic acid, ifosfamide and prednisone combination therapy in patients with relapsed and refractory multiple myeloma. Onco Targets Ther. 2015;8:775-81.

109. Sivaraj D, Green MM, Kang Y, Long GD, Rizzieri DA, Li Z, Garrett AH, McIntyre JL, Chao NJ, Gasparetto C. Bendamustine, pomalidomide, and dexamethasone for relapsed and/or refractory multiple myeloma. Blood Cancer J. 2018;8(8):71.

110. Goldsmith SR, Fiala MA, Wang B, Schroeder MA, Wildes TM, Ghobadi A, Stockerl-Goldstein K, Vij R. DCEP and bendamustine/prednisone as salvage therapy for quad- and penta-refractory multiple myeloma. Ann Hematol. 2020;99(5):1041-8.

111. Leng S, Bhutani D, Raza S, Assal A, Pan S, Hu J, Wei A, Mapara M, Lentzsch S. Phase I/II study of carfilzomib, bendamustine, and dexamethasone (CBD) in patients with newly diagnosed multiple myeloma. Blood Cancer J. 2020;10(2):13.

112. Zhou X, Steinhardt MJ, Grathwohl D, Meckel K, Nickel K, Leicht HB, Krummenast F, Einsele H, Rasche L, Kortüm KM. Multiagent therapy with pomalidomide, bortezomib, doxorubicin, dexamethasone, and daratumumab ("Pom-PAD-Dara") in relapsed/refractory multiple myeloma. Cancer Med. 2020;9:5819-26.

113. Wickström M, Nygren P, Larsson R, Harmenberg J, Lindberg J, Sjöberg P, Jerling M, Lehmann F, Richardson P, Anderson K, et al. Melflufen-a peptidase-potentiated alkylating agent in clinical trials. Oncotarget. 2017;8(39):66641-55.

114. Slipicevic A, Munawar U, Stühmer T, Aschan J, Lehmann F, Nupponen NN, Miettinen J, Huppunen M-E, Heckman CA, Mateos M-V, et al. Abstract 1843: melflufen efficacy in multiple myeloma with TP53 aberrations. Cancer Res. 2020;80(16 Supplement):1843-1843.

115. Richardson PG, Oriol A, Larocca A, Bladé J, Cavo M, Rodriguez-Otero P, Leleu X, Nadeem O, Hiemenz JW, Hassoun H, et al. Melflufen and dexamethasone in heavily pretreated relapsed and refractory multiple myeloma. J Clin Oncol. 2021;39(7):757-67.

116. Heng $\mathrm{HH}$. Chapter 3-genome chaos and macrocellular evolution: how evolutionary cytogenetics unravels the mystery of cancer. In: Heng HH, editor. genome chaos. Cambridge: Academic Press; 2019. p. 95-168.

117. Ye CJ, Sharpe Z, Alemara S, Mackenzie S, Liu G, Abdallah B, Horne S, Regan S, Heng HH. Micronuclei and genome chaos: changing the system inheritance. Genes (Basel). 2019;10(5):366.

118. Lin JK, Muffly LS, Spinner MA, Barnes Jl, Owens DK, Goldhaber-Fiebert JD. Cost effectiveness of chimeric antigen receptor T-cell therapy in multiply relapsed or refractory adult large B-cell lymphoma. J Clin Oncol. 2019;37(24):2105-19.

119. Ho LD, Oso SO, Levine AD. Medical crowdfunding to access CAR T-cell therapy. Lancet Oncol. 2019;20(8):1062-4.

\section{Publisher's Note}

Springer Nature remains neutral with regard to jurisdictional claims in published maps and institutional affiliations.
Ready to submit your research? Choose BMC and benefit from:

- fast, convenient online submission

- thorough peer review by experienced researchers in your field

- rapid publication on acceptance

- support for research data, including large and complex data types

- gold Open Access which fosters wider collaboration and increased citations

- maximum visibility for your research: over $100 \mathrm{M}$ website views per year

At BMC, research is always in progress.

Learn more biomedcentral.com/submissions 